\title{
Collagens in avian neural crest development: distribution in vivo and
}

\section{migration-promoting ability in vitro}

\author{
ROBERTO PERRIS $^{1, *}$, DANUTA KROTOSKI ${ }^{2}$ and MARIANNE BRONNER-FRASER ${ }^{1}$ \\ ${ }^{1}$ Developmental Biology Center, University of Californa Irvine, Irvine, CA, 92717, USA \\ ${ }^{2}$ Fogarty International Center, National Institutes of Health, Bethesda, MA, 20892, USA \\ * Author for correspondence
}

\section{Summary}

This study examines the spatiotemporal distribution of collagen (Col) types $I-V$ and $I X$ during neural crest development in vivo and their ability to support neural crest cell movement in vitro. Col I, III and IV were widespread throughout the embryo, including the neural crest migratory pathways, whereas Col II, V and IX preferentially localized to regions from which migrating neural crest cells were absent. Col I-IV and IX occurred both in association with basement membranes and within interstitial matrices, whereas Col V only was detected in juxtaposition to basement membranes. Although initially distributed throughout the rostrocaudal extent of the somitic sclerotome, Col I and III rearranged to the caudal portion with progressive neural crest cell migration through the rostral portion of the sclerotome. This rearrangement does not occur in neural crest-ablated embryos, suggesting that it is a direct consequence of neural crest cell migration. The perinotochordal matrix, avoided by neural crest cells, contained a metameric Col II/IX immunoreactivity along the rostrocaudal axis which alternated with that of $\mathrm{Col} I$ and III. In contrast, Col IV and V were not observed in this matrix, but lined the basement membranes of the notochord and ventrolateral neural tube. To determine their functional significance for neural crest cell migration in vivo, purified collagens were tested for their ability to promote neural crest cell motility in vitro.
Neural crest cell migration on isolated collagens was most pronounced on Col I and IV, whereas Col II, V and the triple-helical fragment of Col VII were unable to support cell motility. Substrata created by copolymerization of Col I and fibronectin, or Col I and laminin-nidogen, supported cell motility better than Col I alone, whereas both Col $\mathrm{V}$ and a cartilage-type chondroitin sulfate proteoglycan reduced cell movement on Col I. Fibronectin bound to pre-immobilized monomeric Col I, II or V had a reduced ability to support neural crest cell movement when compared to fibronectin alone. A similar reduction was seen for Col IV bound to the low density heparan sulfate proteoglycan from the EHS mouse tumor. The results demonstrate that Col I-IX are differentially distributed in the early avian embryo. During neural crest development several of these collagens undergo dynamic reorganizations that correlate with the migration of neural crest cells. Furthermore, various collagens possess distinct abilities to support neural crest cell migration in vitro, and their migration-promoting activity can be modulated by their conformation and/or association with other matrix components.

Key words: collagens, neural crest, avian embryo, cell migration.

\section{Introduction}

Numerous studies have examined the function of individual extracellular matrix constituents during neural crest development. For example, glycoproteins such as fibronectin and laminin promote neural crest cell motility, whereas certain proteoglycans generally inhibit cell movement (reviews by Newgreen and Erickson, 1986; Perris and Bronner-Fraser 1989; Perris; 1991). Although considerable information has accumulated regarding the function of certain classes of matrix components, the role of collagens remains poorly understood. Some data are available on the distribution of the interstitial collagen types I-III (Col I-III) and the basement membrane collagen type IV during avian neural crest development (Martins-Green and Erickson, 1987; Duband and Thiery, 1987; Kosher and Solursh, 1989). The possible involvement of these collagens in the initial guidance of neural crest cell movement is suggested by the presence of interstitial collagen fibrils on the dorsolateral aspect of the neural tube, where they align in the prospective direction of neural crest cell migration (Löfberg et al. 1980; Newgreen, 1989; Perris et al. 1990). 
Tissue culture studies on the interaction of isolated neural crest cells with collagen have shown that substrata of polymeric Col I promote cell migration (Davis, 1980; Davis and Trinkaus, 1981; Newgreen, 1982; Newgreen et al. 1982; Erickson and Turley, 1983; Rovasio et al. 1983; Tucker and Erickson, 1984; Bilozur and Hay, 1988) at a rate which is largely determined by the concentration of the collagen and the presence of serum (Davis and Trinkaus, 1981; Tucker and Erickson, 1984). Amphibian neural crest cells can migrate differentially on monomers/polymers of Col I-VI, showing a clear preference for Col I and VI (Perris and Johansson, 1990).

Previous studies have indicated that Col I-IV are expressed in the avian embryo at stages of neural crest cell development, and that Col I can support neural crest cell movement in vitro in the presence of serum factors. However, changes in the spatial and temporal distribution of collagens during neural crest development have been overlooked and little is known about the ability of collagens to support avian neural crest cell movement in vitro in the absence of serum components. The objectives of this study were: (1) to map the distribution of Col I-IX during the course of neural crest development; and (2) to determine the ability of isolated collagens to stimulate initial neural crest cell migration in vitro, in the presence or absence of other matrix constituents. Our results show that various types of collagens are differentially distributed along neural crest migratory pathways and that some of these collagens become reorganized during the course of neural crest cell migration. Substrata of Col I and IV support extensive neural crest cell movement in vitro in the absence of serum and additional matrix molecules, whereas other collagens show lower or no motilitypromoting activity.

\section{Materials and methods}

\section{Antibodies}

Antisera to Col I and III were generous gifts from $\mathrm{Dr}$ Charles Little, Department of Anatomy, University of Virginia, Charlottesville, VA. These were raised in rabbits and guinea pigs and purified by cross-adsorption chromatography in columns containing immobilized $\mathrm{Col}$ I and III. A number of rabbit antisera against the $\mathrm{NC1}$ and $7 \mathrm{~S}$ domains of human and bovine Col IV (Wieslander $e t$ al. 1985) were received from $\mathrm{Dr}$ Jörgen Wieslander, Department of Biochemistry, Biocarb, Lund, Sweden. The rabbit antiserum to pepsin-extracted, human placental $\mathrm{Col} \mathrm{V}$ with chain composition [alpha1(V)] alpha2(V) was a gift from Dr Helene Sage, Department of Biological Structure, University of Washington, Seattle, WA. The antiserum to chick Col IX, which was donated by $\mathrm{Dr}$ Peter Bruckner, EHT-Zentrum, Zürich, Switzerland, was raised in rabbits against a mixture of the pepsin-extracted high and low molecular weight fragments of chick sternum Col IX, which were separated from Col II and XI by differential salt precipitation. The antiserum was purified by affinity chromatography in columns containing immobilized Col II, XI and IX, and tested by ELISA and immunoblotting for its specificity for Col IX and lack of significant cross-reactivity with Col II and XI (Müller-Glauser et al. 1986; P. Bruckner, personal communication). The affinity purified antiserum to Col II was received from Daniel Hartmann, Centre de Radioanalyse, Pasteur Institute Lyon, Lyon, France. The antiserum was produced in rabbits against $\mathrm{Col} \mathrm{II}$ isolated from bovine cartilage and displays $0.1 \%$ cross-reactivity with Col IX and $3 \%$ cross-reactivity with Col XI (Hartmann, personal communication). All anti-collagen antibodies were tested by immunoblotting for their reactivity with early embryonic collagens. A hen polyclonal antiserum against the $M_{\mathrm{r}} 65000$ cell-binding region of fibronectin was received from $\mathrm{Dr}$ Staffan Johansson, Department of Medical and Physiological Chemistry, Biomedical Center, Uppsala, Sweden. The HNK1 monoclonal antibody (American Tissue Culture, Inc.) was purified from ascites fluid by column chromatography on protamine sulfate followed by ammonium sulfate precipitation.

\section{Source and characteristics of the collagen preparations}

The various purified collagens were obtained as follows: rat tail and bovine skin Col I and intact Col IV dimers isolated from the EHS mouse tumor were purchased from Collaborative Research, Inc.; pepsin-extracted Col II (bovine cartilage), and Col III, Col V and Col VII (human placenta) were obtained from Chemicon Biochemicals Inc., Sigma and Telios Pharmaceuticals, Inc (San Diego). Following pepsin-extraction, Col VII is obtained as a $M_{\mathrm{r}} 185000$ fragment comprising the entire triple-helical region. The purity of these commercial collagen preparations was $90-95 \%$ according to SDSPAGE and amino acid analysis. Two Col V preparations with respective chain compositions alpha1(V), alpha2(V) alpha3(V) and [alpha1(V)] ${ }_{2}$ alpha2(V) were generous gifts from Dr Helene Sage.

\section{Other reagents}

Proteoglycan monomers from bovine nasal cartilage (PG-LA) and a $M_{\mathrm{r}} 40000$ fragment representing the collagen-binding domain of human plasma fibronectin were received from $\mathrm{Dr}$ Staffan Johansson. Human plasma fibronectin was purchased from Collaborative Research Inc., the New York Blood Bank (New York) and Telios Pharmaceuticals Inc. The laminin-nidogen complex and the low density heparan sulfate proteogly. can (LDPG) from EHS mouse tumor were received from Dr Mats Paulsson, E. Müller Institute of Biomechanics, University of Bern, Bern, Switzerland. Human tenascin was purchased from Telios Pharmaceuticals Inc. (San Diego).

\section{Neural crest ablation}

Ablations of the neural crest in situ were performed as described previously (Ranscht and Bronner-Fraser, 1990). Briefly, eggs incubated to stage 12-14 (15-24 somite pairs) were windowed and the vitelline membrane was removed. A $600-800 \mu \mathrm{m}$ segment of the dorsal neural tube (containing premigratory neural crest cells) adjacent to the last few somites and segmental plate was removed microsurgically using glass needles. Operated embryos then were allowed to develop for 1.5-2 days before being processed for immunohistochemistry.

\section{Immunohistochemistry}

Unoperated and neural crest-ablated chick embryos at developmental stages $15-23$ were fixed in methanol at $4^{\circ} \mathrm{C}$ overnight, rinsed in $0.1 \mathrm{M}$ phosphate buffer, $\mathrm{pH} 7.2$, and transferred to $5 \%$ sucrose in the same buffer, followed by $15 \%$ sucrose, and finally embedded in $7 \%$ gelatin (Sigma, 300 Bloom) in $15 \%$ sucrose. Transverse and longitudinal sections through the mid-trunk level of the embryo were cut at $10-13 \mu \mathrm{m}$. The sections then were mounted on gelatinized 
slides. Antisera against Col I-III, V and IX. were applied at final dilutions of $1: 20-1: 100$ in $0.01 \mathrm{M}$ phosphate buffer, pH 7.2, containing $0.1 \%$ BSA. Incubation "with anti-Col II and anti-Col IX antisera and, in some cases, antisera to Col I and Col III, was preceded by enzymatic digestion with either testicular (250i.u. ml ${ }^{-1}$; Sigma) or Streptomyces (115i.u. $\mathrm{ml}^{-1}$; Sigma) hyaluronidase in $0.1 \mathrm{~m}$ sodium acetate buffer, pH 5.2, containing $25 \mu \mathrm{g} \mathrm{ml}^{-1}$ ovomucoid (trypsin inhibitor O-IV; Sigma), $1 \mathrm{~mm}$ PMSF, $1 \mathrm{~mm}$ EDTA, $1 \mathrm{~mm}$ iodoacetidamine (Sigma) and $200 \mathrm{~K} \cdot \mathrm{u} . \mathrm{ml}^{-1}$ aprotonin (Sigma) for 1 to $3 \mathrm{~h}$ at $37^{\circ} \mathrm{C}$. The antiserum to $\mathrm{Col} \mathrm{V}$ was also tested in combination with treatment of the sections with bacterial collagenase (type VII, Sigma) for $1 \mathrm{~h}$ at $37^{\circ} \mathrm{C}$ (Fitch et al. 1984) in the presence of the same protease inhibitors as used for hyaluronidases, or following pretreatment of the sections with $0.1 \mathrm{~m}$ glacial acetic acid with or without $0.1 \mu \mathrm{g} \mathrm{ml}^{-1}$ pepsin (Sigma) for $10-30 \mathrm{~min}$ at room temperature (Linsenmayer et al. 1983). Antibody-antigen binding was visualized by indirect immunofluorescence using Ig-class and species-specific secondary antibodies, directly conjugated to fluorescein, rhodamine or Texas Red (Zymed Laboratories, Inc). A series of double-labellings were also carried out with antisera to Col I or Col III and the monoclonal HNK-1, and with antisera to Col III and Col IX. Labelled sections were mounted in glycerol-Tris- $\mathrm{HCl}, \mathrm{pH} 8.0$, containing $2 \mathrm{mg} \mathrm{ml}^{-1}$ 1,4-diazabicyclo $(2,2,2$, octane.

For staining of neural crest cells in vitro with antisera to various collagens, neural tube-neural crest explants were grown on fibronectin or monomeric Col I under serum-free conditions for $16-20 \mathrm{~h}$ (see below). Cultures were then fixed in $2 \%$ paraformaldehyde in $0.05 \mathrm{M}$ phosphate buffer, $\mathrm{pH} 7.2$, for 20-30 min at room temperature, extensively rinsed in the same buffer, and stained with the various anti-collagen antisera according to the procedure described above. Cultures were incubated with the various antisera with or without preceding permeabilization with Triton $\mathrm{X}-100(0.025 \%$ in PBS for $5 \mathrm{~min}$ ).

\section{Preparation of culture substrata}

Native three-dimensional substrata of polymeric Col I-III were produced in $35 \mathrm{~mm}$ cell culture dishes (Nuncleon, Denmark) according to conventional procedures. Briefly, the acid cold collagens were diluted in serum-free Eagle's Minimal Essential Medium (MEM) to a concentration of $600 \mu \mathrm{g} \mathrm{ml}^{-1}$ and neutralized over ice under sterile conditions. Dishes containing $0.5 \mathrm{ml}$ of this solution were incubated at $37^{\circ} \mathrm{C}$ for $2-4 \mathrm{~h}$ to allow optimal polymerization of the collagens to occur. Alternatively, the acid Col I solution was dialyzed against PBS at $4^{\circ} \mathrm{C}$, diluted to desired concentrations and similarly polymerized at $37^{\circ} \mathrm{C}$. In some cases, the neutralized Col I solution was supplemented with various relative mass ratios of Col III-V to reach a total collagen concentration of $600 \mu \mathrm{g} \mathrm{ml}^{-1}$, or with $0.1-100 \mu \mathrm{g} \mathrm{ml}^{-1}$ of fibronectin, tenascin or laminin-nidogen complex $\left(600 \mu \mathrm{g} \mathrm{ml}^{-1}\right.$ of Col I plus additional proteins), prior to polymerization. Dehydrated fibrillar substrata of interstitial collagens were prepared by allowing the polymerized collagen lattices to air dry for 2-4 days at room temperature under aseptic conditions. The ultrastructural characteristics of hydrated and dehydrated polymeric substrata of Col I produced according to these protocols have been described previously (Newgreen, 1982). In a set of experiments, dehydrated polymeric substrata of Col I $\left(300 \mu \mathrm{g} \mathrm{ml}^{-1}\right)$ were incubated with $70 \mu \mathrm{g} \mathrm{ml}^{-1}$ of the collagen-binding fragment of fibronectin (corresponding to a molar equivalent of about $800 \mu \mathrm{g} \mathrm{ml}^{-1}$ intact fibronectin) for $2-4 \mathrm{~h}$ at $37^{\circ} \mathrm{C}$ prior to plating of the cells. Monomeric collagen substrata were generated by diluting the acid monomeric collagens in $0.05 \mathrm{M}$ sodium bicarbonate buffer, $\mathrm{pH} 9.6$ (Voller's buffer), to the desired coating concentrations and by allowing the collagens to bind to the plastic at $4^{\circ} \mathrm{C}$ overnight (Perris and Johansson, 1987, 1990; Perris et al. 1989). Following coating, dishes were extensively rinsed with PBS and incubated with $0.5 \%$ ovalbumin $/ 2 \%$ BSA (grades DI and V; Sigma) in Voller's buffer for $2 \mathrm{~h}$ at $37^{\circ} \mathrm{C}$ to cover uncoated areas of the plastic. Fibronectin was coupled at $100-300 \mu \mathrm{g} \mathrm{ml}^{-1}$ (in PBS) to monomeric Col I by incubation at $4^{\circ} \mathrm{C}$ overnight. Mixed substrata with relative proportions of intact Col IV dimers and the triple-helical fragment of Col VII were produced by coating dishes with decreasing concentrations of Col VI $\left(100-0.01 \mu \mathrm{g} \mathrm{ml}^{-1}\right)$ followed by a second coating with $10 \mu \mathrm{g} \mathrm{ml}^{-1}$ of Col IV. Alternating parallel tracks of Col IV and VII were produced by sequential coatings with the two molecules as described previously (Perris and Johansson, 1987; Perris et al. 1989).

\section{Solid-phase binding assays}

The relative binding of fibronectin and various collagens to plastic, or to their potential matrix ligands previously immobilized onto plastic, was determined by using biotinylated proteins as described elsewhere (Perris and Johansson, 1987; Perris et al. 1989). Proteins were biotinylated with biotin- $\beta$-aminocaproic acid $N$-hydroxysuccimide ester (Calbiochem) and binding of the biotinylated molecules was assessed using a strepavidin-horseradish peroxidase complex (Amersham) and a indamine dye substrate for the peroxidase. All primary coatings were performed in Voller's buffer at $4^{\circ} \mathrm{C}$ overnight. Blocking of noncoated plastic surface was carried out by incubation with $1 \%$ ovalbumin in Voller's buffer for $2-4 \mathrm{~h}$ at $37^{\circ} \mathrm{C}$. All secondary coatings were similarly carried out at $4^{\circ} \mathrm{C}$ overnight with the biotinylated molecules dissolved in $0.1 \mathrm{M}$ phosphate buffer, $\mathrm{pH} 7.2$, containing $0.15 \mathrm{M} \mathrm{NaCl}$. No binding of any of the molecules tested in these assays was detected to ovalbumin. For estimation of the binding affinity of fibronectin to various collagens, substrata of Col I-VI $\left(10-100 \mu \mathrm{g} \mathrm{ml}^{-1}\right.$ coating except dehydrated polymeric Col I that was $300 \mu \mathrm{g} \mathrm{ml}^{-1}$ ) were incubated with various concentrations of biotinylated fibronectin (following blocking with $1 \%$ ovalbumin) at $4^{\circ} \mathrm{C}$ or $37^{\circ} \mathrm{C}$ for $12-18 \mathrm{~h}$ in PBS. In some cases, monomeric Col I was preincubated for $2-4 \mathrm{~h}$ at $37^{\circ} \mathrm{C}$ with $70 \mu \mathrm{g} \mathrm{ml}^{-1}$ (in PBS) of the collagen-binding fragment of fibronectin prior to incubation with intact biotinylated fibronectin. Binding of biotinylated fibronectin to preimmobilized fibronectin at $4^{\circ} \mathrm{C}$ was $<15 \%$ of the binding detected to Col I indicating that the effect of self-aggregation of the glycoprotein was largely negligible. To determine whether fibronectin detached more readily from the collagen monomers than from plastic during the culture period, wells with fibronectin alone and Col I-bound fibronectin were incubated with $200 \mu \mathrm{l}$ culture medium for $16 \mathrm{~h}$ at $37^{\circ} \mathrm{C}$, prior to incubation with streptavidin-horseradish peroxidase. Detachment of fibronectin from plastic and monomeric Col I was indistinguishable and was $<20 \%$ of the total amount bound. Binding of intact Col IV dimers to immobilized LDPG was tested on intact and heparitinase-digested proteoglycan. For the latter purpose, $500 \mu \mathrm{g} \mathrm{LDPG}$ were dissolved in $1 \mathrm{ml} 0.05 \mathrm{M}$ Tris- $\mathrm{HCl}$, pH 7.4, containing $45 \mathrm{mU}$ heparitinase (ICN Biochemicals, Inc.) and incubated for $4-6 \mathrm{~h}$ at $37^{\circ} \mathrm{C}$. The enzymatic reaction was stopped by addition of $10 \mathrm{~mm}$ EDTA and the solution was extensively dialyzed against Voller's buffer at $4^{\circ} \mathrm{C}$. Microwells were coated with $10 \mu \mathrm{g} \mathrm{ml}^{-1}$ of intact or heparitinase-digested LDPG, which is a coating concentration known to yield maximal binding of the proteoglycan to plastic (Perris et al. 1989), followed by 
incubation with increasing amounts of biotinylated Col IV. To ascertain that heparitinase treatment of LDPG did not affect its ability to bind to plastic and thereby affect the total amount of Col IV that became bound to the substratum, LDPG also was heparitinase-digested after immobilization to plastic. The two procedures yielded equivalent results. Control wells received other biotinylated collagens, including pepsindigested $\mathrm{Col}$ IV lacking its $\mathrm{NC1}$ heparin-binding domain. Binding of these collagens to LDPG was $>20 \%$ of that detected for intact Col IV dimers, with the exception of Col V that bound to $42 \%$ of the maximal detected for Col IV. Incubation of immobilized LDPG with biotinylated Col IV in the presence of exogenous heparin resulted in a similar inhibition of the LDPG-Col IV interaction as that observed after heparitinase digestion of LDPG.

\section{Cell migration assay}

The extent of neural crest cell migration on various substrata was determined by computerized morphometry, according to a previously published procedure (Perris et al. 1989). Briefly, neural tube-neural crest explants were isolated from 2-days quail embryos, plated onto various substrata, and cultured for $16 \mathrm{~h}$ in serum-free MEM containing $0.1 \%$ ovalbumin. In the case of hydrated polymeric Col I, the explants were plated either onto polymerized $\mathrm{Col} \mathrm{I}$ in $550 \mu \mathrm{l}$ MEM, or were added to the nonpolymerized Col I solution, which then was allowed to polymerize for $1-2 \mathrm{~h}$ at $37^{\circ} \mathrm{C}$ prior to addition of the culture medium. After $16 \mathrm{~h}$ of culture, the predominant neural crest cell outgrowth on the dorsal side of the neural tube explant was photographed in an inverted microscope. The negatives were enlarged 123.5 times and the contours of the outgrowth traced on a sheet of paper and analyzed with a Sigma-Scan morphometry program (Jandel Scientific, Inc.; Perris et al. 1989). As a modification of the previously published procedure, the area of neural crest cell outgrowth was normalized to the length of the neural tube explant. This was accomplished by assigning the average neural tube length on 'control' fibronectin substrata a value of 1 and by multiplying values for the areas of outgrowth on the tested substrata by a factor of $1 / x$ (where $x=$ the average neural tube length on the given substratum). In some experiments, explants plated on polymeric $\mathrm{Col}$ I were supplemented after $2-3 \mathrm{~h}$ of culture with $0.1-100 \mathrm{~m} \mathrm{ml}^{-1}$ soluble fibronectin, laminin-nidogen complex, the collagen-binding fragment of fibronectin $\left(70 \mu \mathrm{g} \mathrm{ml}^{-1}\right)$, or the antiserum to the cell-binding region of fibronectin $\left(120 \mu \mathrm{g} \mathrm{m}^{-1}\right.$; the last two separately or in combination). Eleven to twenty four explants were analyzed for each experimental case. The two-sided Student $t$ test was used to establish statistical significance which was defined here as $P<0.001$.

\section{Results}

\section{Distribution of Col I-V, and IX during neural crest development}

Col I and III were largely co-localized throughout the trunk region at all stages of neural crest cell migration. At initial and advanced stages of cell movement, immunoreactivity for both Col I and Col III was detected in interstitial matrix networks and in association with basement membranes (Fig. 1A,B). Col I and Col III immunoreactive fibrils were widespread throughout the dispersing sclerotome and were particularly concentrated in the intersomitic clefts (Fig. 2A). As neural crest cells first entered the rostral half of the somites, the fibrillar immunolabelling for $\mathrm{Col} I$ and $\mathrm{Col}$ III was widespread throughout the somitic sclerotome (Fig. 2A). With progressive neural crest cell migration, however, Col I and III immunoreactive fibrils gradually became excluded from the rostral half of the sclerotome containing the neural crest cells (Figs 2B, 3A). Doublelabelling with anti-Col I or anti-Col III antisera and the HNK-1 monoclonal antibody, which recognizes migrating neural crest cells, confirmed that this re-organization of the collagenous matrix inversely correlated with the colonization of the rostral half of the somites by the migrating cells (Figs 2B, 3B). Moreover, at the level of the notochord, the rostrocaudal distribution of Col I and III appeared segmental, extending into the ventral sclerotome and perinotochordal region at sites of prospective ganglion formation (Fig. 1B), but weak or absent in interganglionic regions (Fig. 1A).

In embryos in which the neural crest was ablated in whole or in part, Col I and III staining within the sclerotome was present in both rostral and caudal halves of the somites, although the immunoreactivity tended to be more pronounced in the caudal than the rostral half of the sclerotome (Fig. 2C,D). The intensity of immunoreactivity was strongest in rostral regions of the embryo, indicating a rostral-to-caudal sequence in deposition of the collagens during development. No immunoreactivity was observed on the surface of moving neural crest cells at any phase of migration. Following gangliogenesis, Col I and Col III were absent from sensory ganglia, but were abundant in the surrounding sclerotome (Figs $1 \mathrm{D}, \mathrm{E}$ and $3 \mathrm{C}-\mathrm{F}$ ). High levels of immunoreactivity also were observed in dense bundles that apposed the basement membrane of the ventrolateral neural tube and notochord (Figs 1D,E).

In contrast to Col I and III, Col IV was primarily localized in basement membranes (Martins-Green and Erickson, 1987; Duband and Thiery, 1987; and our own observations). However, at stages of advanced neural crest cell migration, the collagen also was detected in fine interstitial fibrils throughout the sclerotome (Fig. 4A). This fibrillar Col IV network remained uniform along the rostrocaudal extent of the sclerotome during the course of neural crest cell migration through the rostral half of the sclerotome. After the ganglia had formed, Col IV could be detected both within the ganglia and the surrounding sclerotome (Fig. 4B), where it becomes progressively fainter at more advanced stages of development.

During the neural crest cell migratory phase, Col IX immunoreactivity was exclusively detected in association with the notochordal basement membrane (Fig. 1C), whereas Col II immunoreactivity delineated the neural tube and the basal side of the ectoderm (data not shown). These observations are in agreement with a previous report (Kosher and Solursh, 1989). Hyaluronidase treatment of the sections prior to antibody application revealed that the fibrillar matrix emanating from the notochord into the ventral sclerotome contained both Col II and Col IX. When analyzed in the rostrocaudal dimension, this immunoreactivity appeared metameric, with the most pronounced staining 

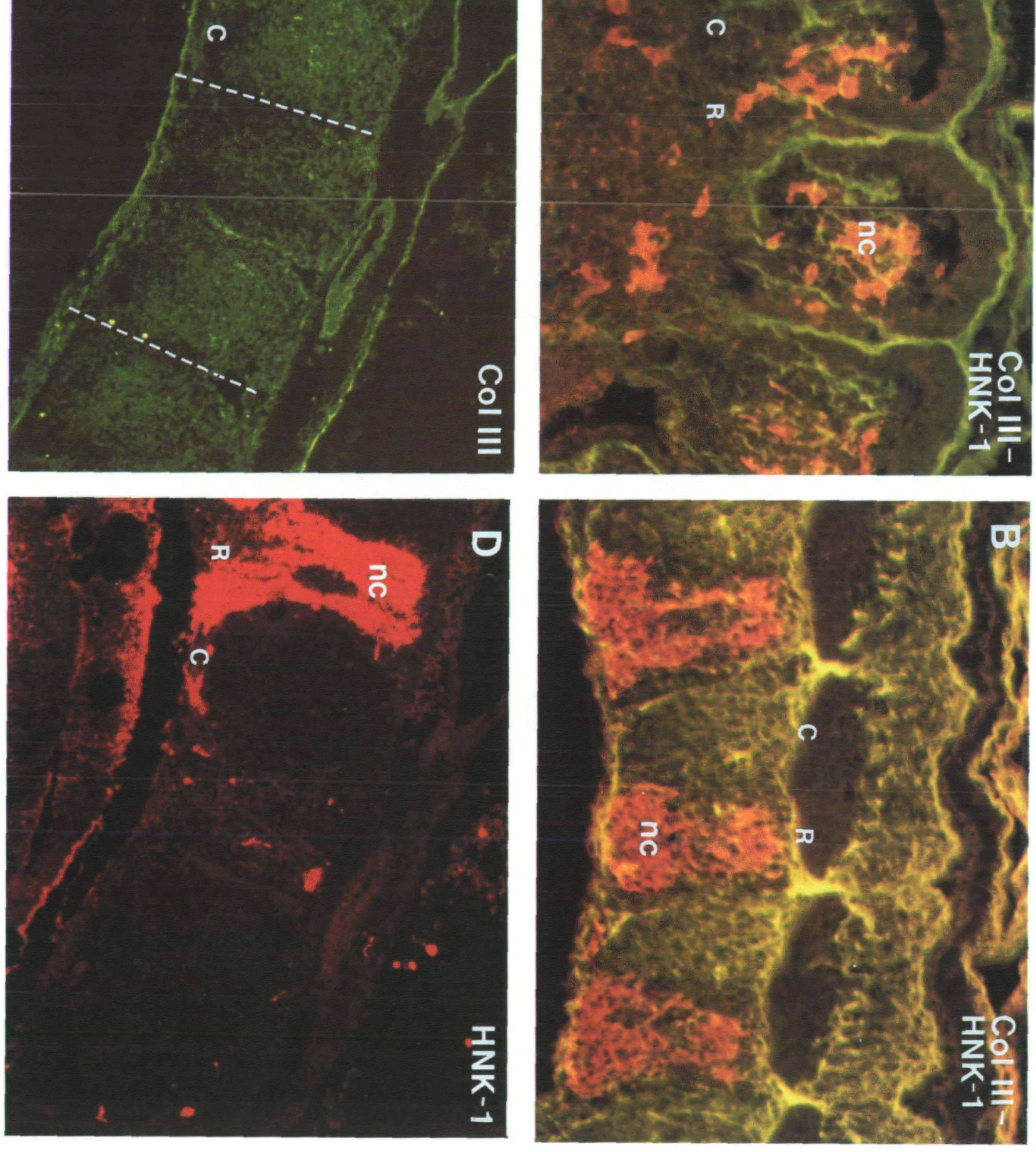

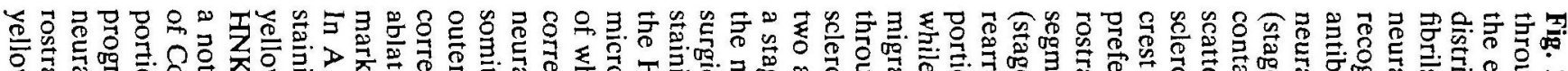

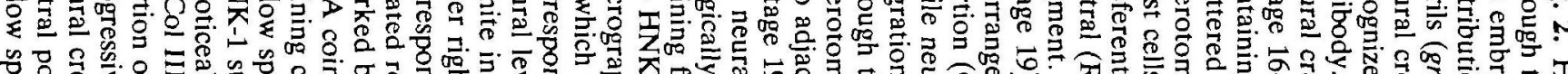

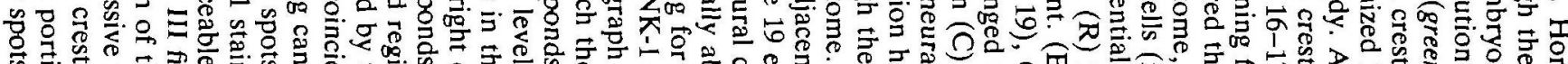

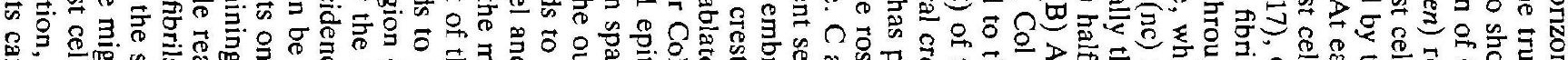



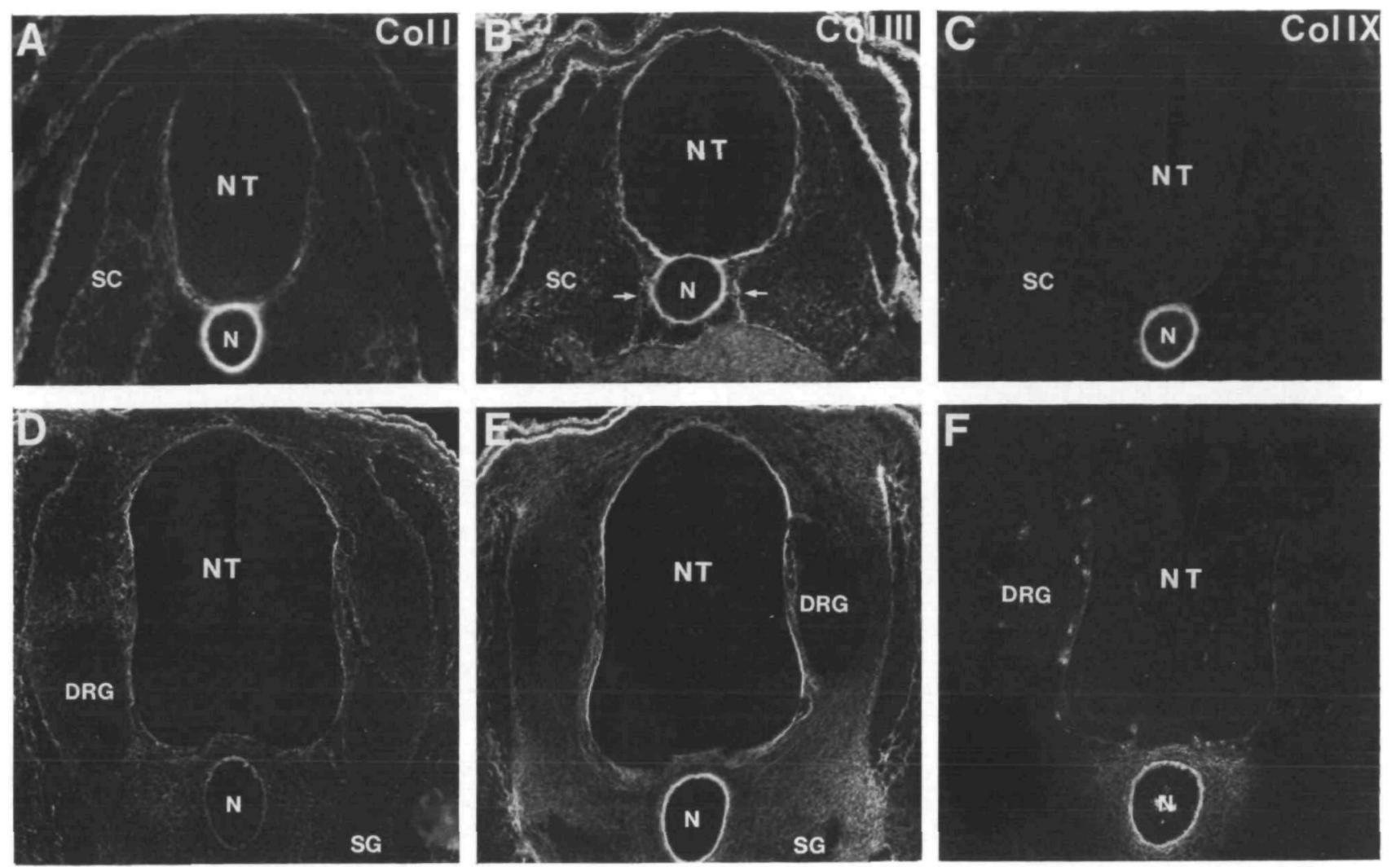

Fig. 1. Transverse sections showing the distribution of Col I, III and IX in the trunk region at stages of advanced neural crest cell migration (stage 17; A, B, C) and following gangliogenesis (stages 22-23; D, E, F). Immunohistochemical staining illustrated in A and B are representative of different axial levels (prospective ganglion formation/rostral sclerotome and caudal sclerotome respectively) and exemplify the metameric distribution of Col I and Col III in the perinotochordal. Arrows in B mark the extension of the Col III (/Col I)-containing fibrillar matrix of the perinotochordal region at axial levels of prospective ganglion formation. Hyaluronidase predigestion of the sections reveals Col IX immunoreactivity in the matrix occupying the perinotochordal space. This immunoreactive pattern was similar to that observed for Col II (not shown). DRG, dorsal root ganglia; SG, sympathetic ganglia; $N$, notochord; NT, neural tube.

at the boundary between two adjacent somites, corresponding to the level of prospective vertebral arch formation. The fibrillar staining for Col II and IX in the perinotochordal region coincided with that of cartilagetype proteoglycans (Perris et al. 1991a). During and after gangliogenesis, the metameric pattern of Col II and IX immunoreactivity in the perinotochordal matrix seemed to alternate with that of Col I and Col III (Fig. 4E-G). Thin lines of Col II and Col IX immunoreactivity also were observed around the neural tube after formation of the peripheral ganglia, whereas no Col II was detectable subepidermally at these stages of development. The staining pattern for Col IX was not affected by pretreatment of the sections with chondroitinase $\mathrm{ABC}$ or $\mathrm{AC} \mathrm{II}$, indicating that the antiserum displayed little or no reactivity with the chondroitin/dermatan sulfate chain(s) of the collagen (Bruckner et al. 1985).

Col V was not immunohistochemically detectable at stages of initial neural crest cell migration, but was prominent around the notochordal basement membrane by advanced stages neural crest cell migration and following gangliogenesis (Fig. 4C,D). A thin line of immunoreactivity also was observed along the neural tube basement membrane, particularly in the ventral portion. Immunoreactivity for Col $\mathrm{V}$ was not altered by pretreatment of the sections with dilute acetic acid, with or without $0.1 \mu \mathrm{g} \mathrm{ml}^{-1}$ pepsin (Linsenmayer et al. 1983), or by bacterial collagenase predigestion which has been shown previously to unmask epitopes on Col V fibrils of the avian corneal matrix (Fitch et al. 1984).

\section{Collagen immunoreactivity in neural tube-neural crest cultures}

The explanted neural tube deposited an extensive fibrillar network containing both Col I and Col III (Fig. 5A,B), and sparse fibrils of Col IV. In contrast, no immunoreactivity for Col II and V could be detected. Generally, the neural tube-associated network of Col I was assembled into larger fibrils and fibril bundles that were concentrated along the midline of the explant, whereas Col III appeared uniformly distributed in finer fibrils. In cultures where the notochords were retained on the ventral side of neural tube explants, a prominent surface labelling for Col I-III (Fig. 5B) and IV (not shown) could be seen along the entire notochord. Dispersed neural crest cells in these cultures did not 

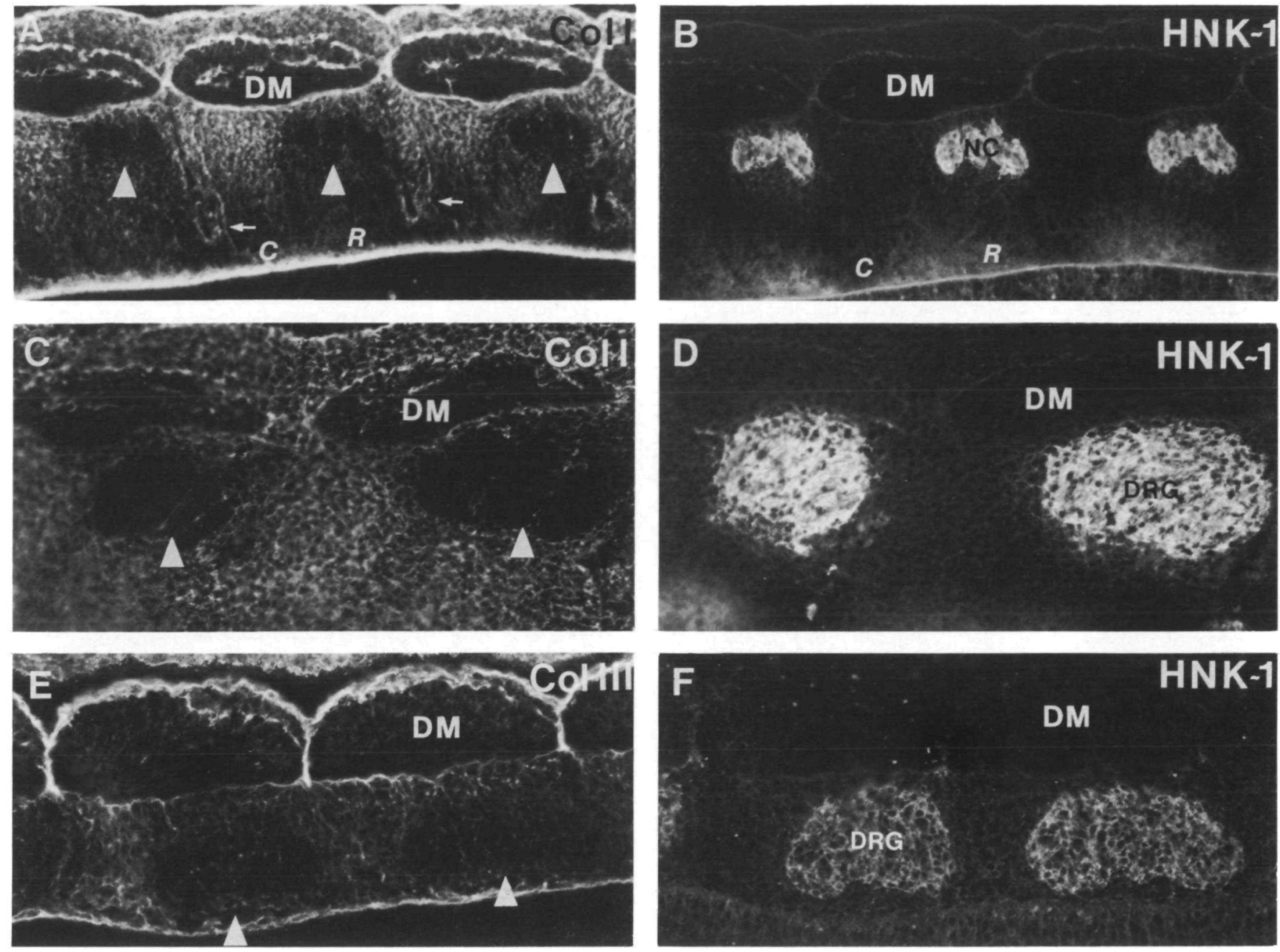

Fig. 3. Sagittal and parasagittal sections through embryos at developmental stages corresponding to advanced stages of neural crest cell migration and the formation of dorsal root ganglia (stages 18-20; arrowheads A-B) and following gangliogenesis (stages 22-23; C-F) further illustrating the rearrangement of Col I and III fibrils within the sclerotome. The sections were double-labelled as in Fig. 2 with the HNK-1 antibody and either the anti-Col I antiserum (A-D) or the anti$\mathrm{Col}$ III antiserum (E,F). In the micrographs, the rostrocaudal orientation of the sections is from right to left and neural crest cell migration occurs from bottom to top. Note also the pronounced alignment of fibril bundles within the intersomitic clefts (arrows). Following gangliogenesis, Col I and III were widespread within the sclerotome, but were virtually absent from the ganglia $(\mathrm{G})$. DM, dermomyotome.

express Col I and III immunoreactivity (Fig. 5C,D), or any of the other collagens (data not shown).

\section{Neural crest cell migration on isolated collagens}

Neural crest cells migrated extensively on various Col I substrata and to a lesser extent on Col III and IV (Figs 6 and $7 \mathrm{~A}-\mathrm{F}$ ). Adsorbance of various biotinylated collagens to plastic differed somewhat; the interstial Col I-III, and V were slightly less efficient in binding to plastic than Col IV and VII (not shown). However, differences in the motility-promoting capacity of various collagens did not seem to be directly correlated with the amount of protein adsorbed onto plastic. Neural crest cell migration on dehydrated polymeric Col I was significantly more extensive than on hydrated polymers ( $42 \% ; P<0.001$; Figs $6,7 \mathrm{~A}, 8 \mathrm{~A})$, but similar to that on monomeric collagen substrata $(32 \% ; P<0.001$; Fig. 6$)$.
Conversely, monomers and hydrated polymers of Col I were similar in their ability to stimulate neural crest cell movement ( $18 \%$ difference; $P>0.001$ ). The extent of neural crest cell movement on hydrated fibrillar Col I was comparable whether the cells were plated onto the already polymerized collagen network, or whether they were embedded in the collagen lattice prior to polymerization. However, in the former case, cell dispersion predominantly occurred on the surface of the polymer, with little or no penetration of the collagen gel. In contrast, neural crest cells embedded within the Col I polymer tended to move in multiple directions (Fig. 8A). The differential ability of different forms of Col I substrata to promote cell migration was not directly correlated with the amount of collagen in the substratum. In fact, the extent of cell movement on various Col I substrata decreased in the order: 

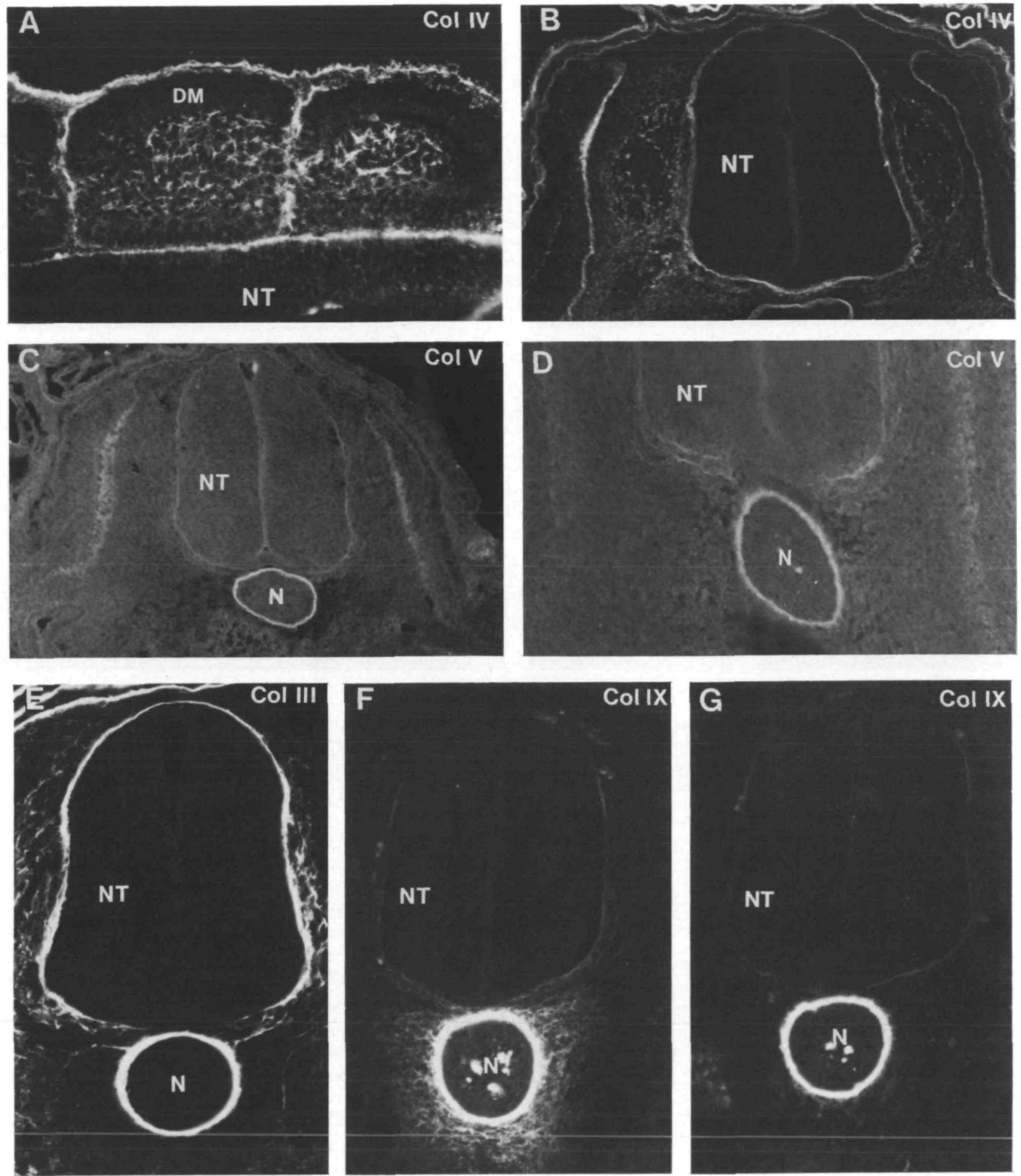

Fig. 4. Transverse and parasagittal sections through the midtrunk region showing the distribution of Col III-IX during and following neural crest cell migration (stage 16-23). (A) Parasagittal section through three somites of the midtrunk stained with the anti-NC1 antiserum to Col IV. In contrast to Col I and III (Fig. 2, 3), the fibrillar Col IV network remained uniform during the migration of neural crest cells through the rostral half of the somites (stage 17). (B) At stages following gangliogenesis (stage 23), Col IV was detected within the ganglia as well as in the surrounding sclerotome. (C,D)

Distribution of Col V at stages of advanced neural crest cell migration (stage 17) and gangliogenesis (stage 22).

(E) Staining for Col III at a stage of advanced neural crest cell migration and initial gangliogenesis (stage 19), showing the lack of immunoractivity in the fibrillar matrix emanating from the notochord into the adjacent sclerotome. (F) Col IX staining at a similar stage and axial level as shown in (E) and illustrating the pronounced occurrence of this collagen in the perinotochordal matrix. (G) Col IX staining in a transverse section cut $100-200 \mu \mathrm{m}$ more rostrally than that represented in (F) and illustrating the metameric distribution pattern of Col IX in the perinotochordal region. 

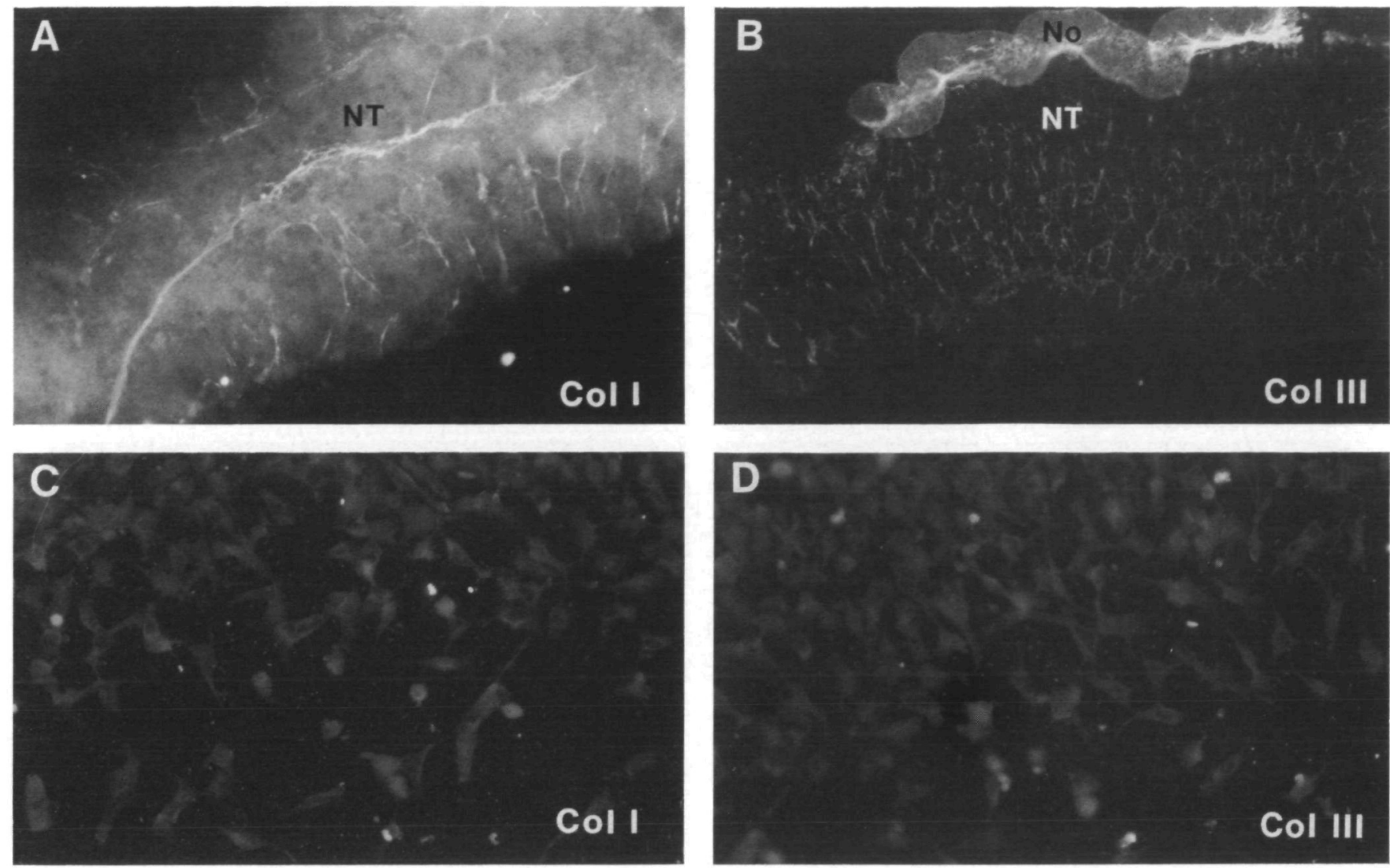

Fig. 5. Immunohistochemical detection of Col I (A and C) and Col III (B and D) in neural tube-neural crest explants after $16 \mathrm{~h}$ of culture in vitro. The neural tubes (NT) deposited a fibrillar matrix containing both Col I and Col III (A,B). Note how Col III was densely distributed in thin fibrils, whereas Col I formed thicker fibril bundles. The notochord (No) pictured in B shows high levels of surface labelling for Col III. In contrast, no immunoreactivity could be detected on the neural crest cells $(C, D)$.

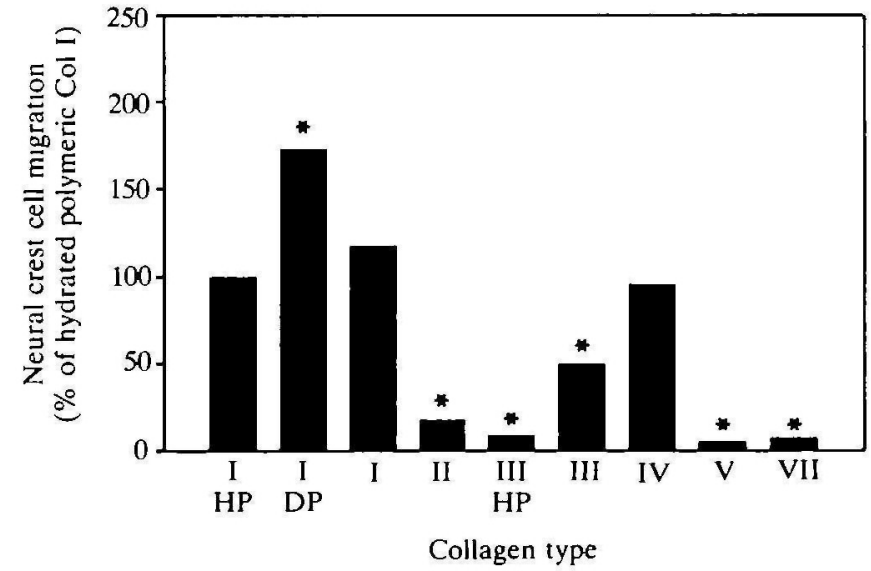

Fig. 6. Neural crest cell migration on various types of collagen substrata, expressed as \% of cell movement on hydrated polymeric (HP) Col I. Unless otherwise indicated, collagens were tested in their monomeric form. Dehydrated polymeric (DP) substrata of Col II were indistinguishable from their monomeric counterparts. The extent of neural crest cell migration on the various collagen substrata decreased in the order: Col I DP $>$ Col I monomer $>$ Col I HP $>$ Col IV $>$ Col III monomer $>$ Col II $>$ Col III HP, where ' $>$ ' implies $P<0.001$. * The extent of neural crest cell migration on this collagen was significantly different than that on hydrated polymeric substrata. dehydrated polymer $\geqslant$ monomer $\geqslant$ hydrated polymer, whereas the amount of collagen in the substrata supporting maximal neural crest cell motility decreased in the order hydrated polymer $\left(600 \mu \mathrm{g} \mathrm{ml}^{-1}\right)>$ dehydrated polymer $\left(300 \mu \mathrm{g} \mathrm{m}^{-1}\right)>$ monomer $\quad(10$ $100 \mu \mathrm{g} \mathrm{ml}^{-1}$ ).

Monomeric but not polymeric Col III was permissive for neural crest cell movement (above the background movement on ovalbumin/BSA alone; Figs 6, 7B), whereas Col II was unable to promote cell motility over background levels in either monomeric or polymeric form (Fig. 6). Migration on monomeric Col III was significantly lower than that on monomeric/polymeric Col I, reaching only $28-49 \%$ of the maximal migration observed on Col I substrata. Since Col I-III showed similar avidity to plastic and the collagens have similar relative molecular masses, it is unlikely that these differences in motility-promoting capacity are due to different amounts of protein in the substratum (in molar equivalents). Although neural crest cell migration on intact Col IV dimers was similar to that observed on hydrated polymeric and monomeric substrata of Col I (5-9\% difference; Figs 6, 7C, 8A), it was significantly lower than that on dehydrated polymeric Col I substrata (45\% difference; $P<0.001$; Figs $6,7 \mathrm{~A}, \mathrm{C}$ ). No migration was observed on mono- 

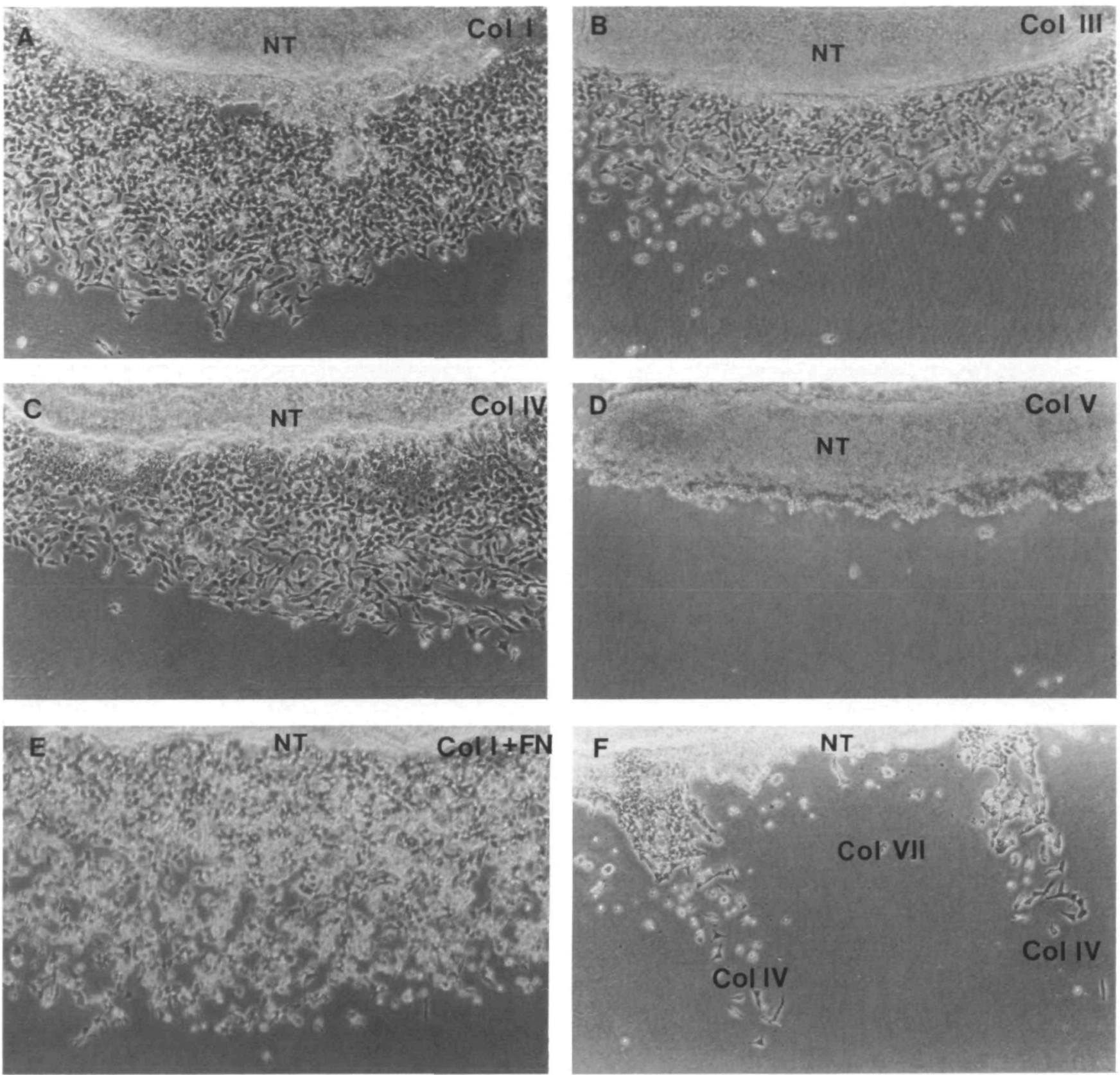

Fig. 7. Phase contrast micrographs showing the extent of neural crest cell migration on dehydrated polymeric Col I (A), monomeric Col III (B), intact dimers of Col IV (C), monomeric Col V (D), fibronectin bound to monomeric Col I (E), and on tracks of Col IV on a background substratum of the triple-helical fragment of Col VII (F) in representative cultures. Note the rounded (poorly adherent morphology) of neural crest cells migrating on Col I-bound fibronectin.

meric substrata of the two forms of Col V, [alpha1(V) $]_{2}$ alpha2(V)] and alpha1(V)alpha2(V)alpha3(V) (Figs 6, 7D). Similarly, no migration was observed on the triplehelical fragment of Col VII (Figs 6, 7F).

To rule out the possibility that the enhanced neural crest cell motility on dehydrated polymeric and monomeric Col I substrata was mediated by low levels of cell surface-bound fibronectin, neural crest cells were plated on dehydrated polymeric/monomeric substrata of $\mathrm{Col} \mathrm{I}$ in the presence of an excess of the collagen- binding fragment of fibronectin alone (found to inhibit the fibronectin-collagen interaction in solid-phase assays), or in combination with an antiserum to the cellbinding region of fibronectin. Neural crest cell movement on Col I substrata was not altered by preincubation with the collagen-binding fragment of fibronectin or anti-fibronectin antiserum (Table 1). A correlation between the ability of various collagen types to promote neural crest cell migration and their distribution in situ is presented in Table 2. 

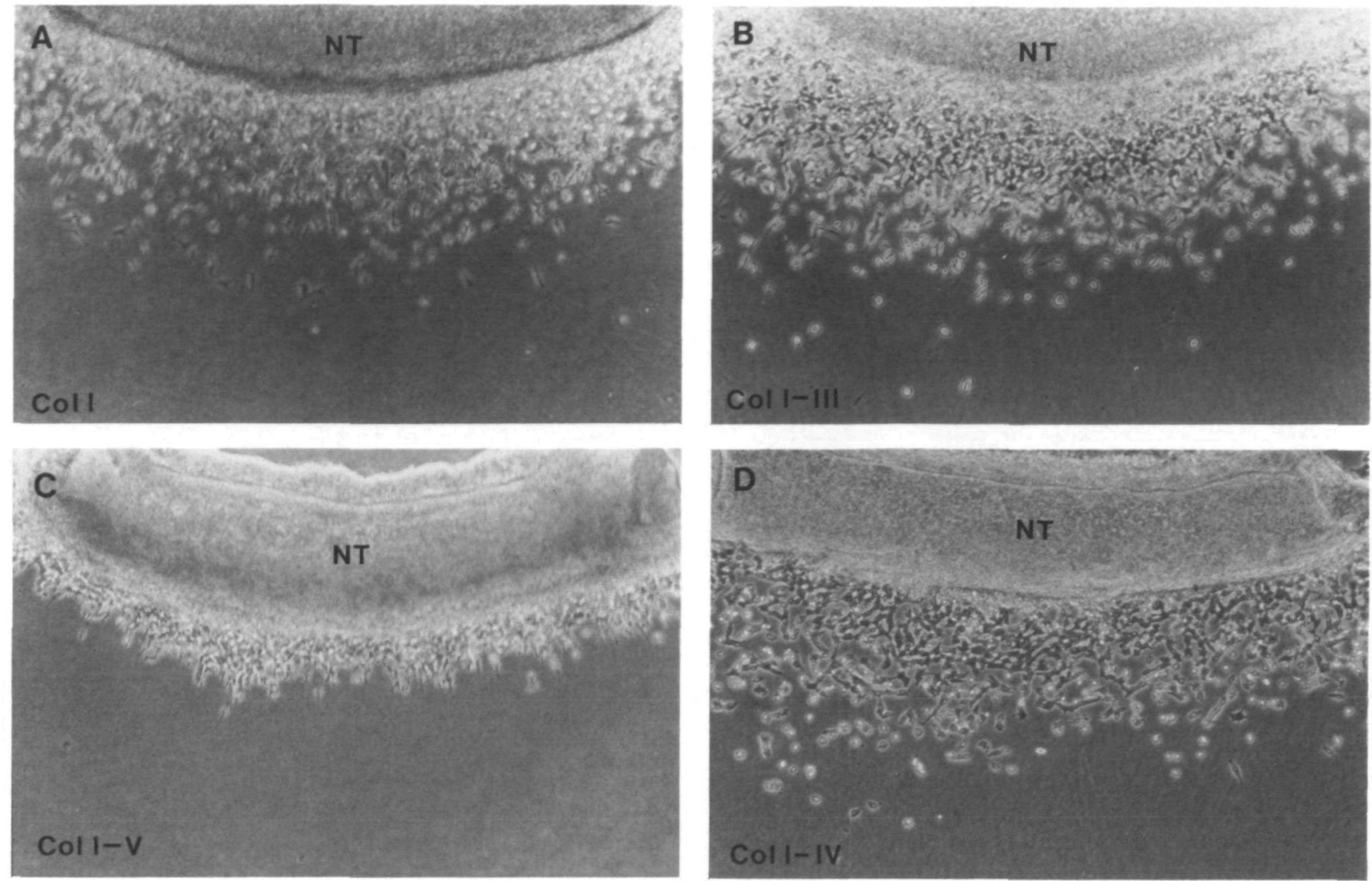

Fig. 8. Phase contrast micrographs illustrating the migration of neural crest cells on polymeric Col I substrata containing various relative mass ratios of Col III-IV. (A) Neural crest cell migration on polymeric Col I alone $\left(600 \mu \mathrm{g} \mathrm{ml}{ }^{-1}\right)$. The micrograph shows a case in which the neural tube-neural crest explant was embedded within the polymerizing Col I lattice and the cells have moved in multiple directions throughout the fibrillar network. (B) On substrata of Col I-III, with a mass ratio of $1: 1\left(300 \mu \mathrm{g} \mathrm{ml}^{-1}\right.$ of Col I: $300 \mu \mathrm{g} \mathrm{ml}^{-1}$ of Col III), the overall extent of neural crest cell migration was not significantly different from that on Col I alone; numerous cells that moved through the collagenous network were frequently rounded in shape. (C) At a Col I-V mass ratio of $1: 0.5\left(480 \mu \mathrm{g} \mathrm{ml}^{-1}\right.$ of Col I:120 $\mathrm{g} \mathrm{ml}^{-1}$ of Col V), neural crest cell migration was limited. Note the orientation of neural crest cells protruding from the neural tube explant in the direction of migration, which is perpendicular to the orientation of the neural tube. Moreover, the penetration frequency was lower than that seen for Col I/III polymers. (D) Copolymerization of Col I and Col IV resulted in a substratum indistinguishable in motility-promoting capacity from that of Col I alone. In this case, virtually no penetration of the polymer can be observed.

Substrata with combinations of two collagen types

$\mathrm{Col} \mathrm{I}$ can associate with $\mathrm{Col}$ III and V in vitro and these interactions are believed to simulate those occurring in vivo (Table 3). Therefore, we tested complex collagen networks for their ability to promote neural crest cell migration by copolymerizing Col I with other collagen types (i.e. Col III, IV or V). Alteration of the relative mass proportion of $\mathrm{Col} \mathrm{I} / \mathrm{Col} \mathrm{III} \mathrm{and} \mathrm{Col} \mathrm{I} / \mathrm{Col} \mathrm{IV}$ (up to $1: 1 ; 300 \mu \mathrm{g} \mathrm{ml}^{-1}$ of Col I: $300 \mu \mathrm{g} \mathrm{ml}^{-1}$ Col of III or IV) did not alter significantly the overall extent of neural crest cell dispersion (17-28\%; Table 1; Figs 8B, 9A). However, the presence of $\mathrm{Col}$ III within Col I polymers stimulated penetration of cells through the polymers (Fig. 8A, B). In addition, neural crest cells within the Col I-III polymers assumed a rounded morphology, which was clearly distinguishable from the multipolar shape observed in cells migrating on the surface of polymers of Col I alone. Copolymerization of $\mathrm{Col} \mathrm{I}$ and
Col V reduced neural crest cell migration by $>80 \%$ at a Col I/V mass ratio of $1: 0.5\left(480 \mu \mathrm{g} \mathrm{ml}^{-1}\right.$ of Col I: $120 \mu \mathrm{g} \mathrm{ml}^{-1}$ of Col V; Figs 8C, 9B).

Because Col IV and VII are known to be ubiquitous within basement membrane-interstitial matrix interfaces (Sakai et al. 1986; Keene et al. 1987a; Bächinger et al. 1990), we simulated in vitro situations where neural crest cells were simultaneously confronted with both collagens. On substrata with relative proportions of immobilized Col IV and VII, the extent of neural crest cell migration was reduced exponentially with increasing amounts of substratum-bound Col VII (Fig. 10B). Alignment of the migration profile with the protein binding profile indicated that the decrease in the extent of neural crest cell movement correlated well with the increase in substratum-bound Col VII, and the corresponding decrease in the amount of Col IV (Fig. 10A). Moreover, when cells were given the choice to migrate 
Table 1. Neural crest cell migration on collagen-fibronectin and collagen-LDPG substrata

\begin{tabular}{|c|c|c|c|c|}
\hline Substratum & Addition & $\begin{array}{l}\text { No. of } \\
\text { explants }\end{array}$ & $\begin{array}{c}\text { Area of } \\
\text { outgrowth } \\
\text { (mm² } \pm \text { s.D.) }\end{array}$ & $\begin{array}{l}\% \text { of } \\
\text { control }\end{array}$ \\
\hline $\begin{array}{l}\text { Col I monomer } \\
\text { Col I monomer }\end{array}$ & $F N(0 h)^{-}$ & $\begin{array}{l}11 \\
14\end{array}$ & $\begin{array}{l}0399 \pm 0.092 \\
0.628 \pm 0.101\end{array}$ & $\begin{array}{l}100 \\
58^{*}\end{array}$ \\
\hline $\begin{array}{l}\text { Col I HP } \\
\text { Col I HP } \\
\text { Col I HP } \\
\text { Col I HP }\end{array}$ & \begin{tabular}{l}
\multicolumn{1}{c}{-} \\
FN $(16 h)$ \\
LN-N $(16 h)$ \\
Col IV
\end{tabular} & $\begin{array}{l}16 \\
14 \\
17 \\
20\end{array}$ & $\begin{array}{l}0.338 \pm 0.130 \\
0.356 \pm 0.124 \\
0.317 \pm 0.092 \\
0.424 \pm 0.086\end{array}$ & $\begin{array}{r}100 \\
5 \\
6 \\
121\end{array}$ \\
\hline $\begin{array}{l}\text { Col I DP } \\
\text { Col I DP } \\
\text { Col I DP } \\
\text { Col I DP } \\
\text { Col I DP }\end{array}$ & \begin{tabular}{l}
\multicolumn{1}{c}{-} \\
FN $(16 \mathrm{~h})$ \\
CBFNf \\
Anti-FN \\
CBFNf+anti-FN
\end{tabular} & $\begin{array}{l}17 \\
15 \\
16 \\
15 \\
15\end{array}$ & $\begin{array}{l}0.584 \pm 0.189 \\
0.528 \pm 0.160 \\
0.452 \pm 0.136 \\
0.549 \pm 0.105 \\
0.592 \pm 0.146\end{array}$ & $\begin{array}{r}100 \\
90 \\
78 \\
94 \\
102\end{array}$ \\
\hline $\begin{array}{l}\text { Col II } \\
\text { Col V } \\
\text { Col IV } \\
\text { Col IV }\end{array}$ & $\begin{array}{l}\text { FN }(0 h) \\
\text { FN }(0 h) \\
\text { LDPG }\end{array}$ & $\begin{array}{l}16 \\
18 \\
22 \\
14\end{array}$ & $\begin{array}{l}0.532 \pm 0.191 \\
0.775 \pm 0.109 \\
0.323 \pm 0.071 \\
0.094 \pm 0.028\end{array}$ & $\begin{array}{c}54^{*} \\
71^{*} \\
100 \\
29^{*}\end{array}$ \\
\hline $\begin{array}{l}\text { FN } \\
\text { FN }\end{array}$ & Anti-FN & $\begin{array}{l}22 \\
11\end{array}$ & $\begin{array}{l}1.085 \pm 0.160 \\
0.508 \pm 0.133\end{array}$ & $\begin{array}{l}100 \\
53^{*}\end{array}$ \\
\hline
\end{tabular}

Note: Substrata of dehydrated polymeric (DP) Col I $\left(300 \mu \mathrm{g} \mathrm{ml}^{-1}\right)$ were tested in the presence of $70 \mu \mathrm{g} \mathrm{ml}^{-1}$ of the collagen-binding fragment of fibronectin (CBFN) alone or in combination with the antiserum $\left(120 \mu \mathrm{g} \mathrm{ml}^{-1}\right)$ to the cell-binding domain of fibronectin (FN). FN was bound to immobilized monomeric $\mathrm{Col} I, \mathrm{Col} \Pi \mathrm{I}$ and $\mathrm{Col} V$ prior to plating of the cells $(0 \mathrm{~h})$, or added soluble to neural crest cells migrating on Col I HP and Col I DP substrata $(16 \mathrm{~h})$. Col IV was copolymerized with Col I at a relative mass ratio of 1:1 (total collagen concentration $=600 \mu \mathrm{g} \mathrm{ml}^{-1}$ ), or bound to preimmobilized LDPG (Table 3). Asterisk indicates that the difference between control substratum and test substratum was found statistically significant (i.e. $P<0.001$ ). Migration on FN bound to collagens was compared to FN directly immobilized onto plastic, whereas in all other cases the control substratum is represented by the first immobilized molecule (Substratum) and test substratum is represented by the combined substratum containing two molecules (Substratum +Addition).

I Neural crest cell migration is expressed as area of outgrowth.

Table 2. Distribution of various collagen types during neural crest (NC) development in relation to their ability to promote cell migration in vitro

\begin{tabular}{lccc}
\hline & \multicolumn{2}{c}{ Distribution in situ } & Motility- \\
\cline { 2 - 4 } Collagen & $\begin{array}{c}\text { NC } \\
\text { migratory } \\
\text { pathways }\end{array}$ & $\begin{array}{c}\text { Areas avoided } \\
\text { by the } \\
\text { NC cells }\end{array}$ & $\begin{array}{c}\text { Mromoting } \\
\text { activity } \\
\text { in vitro }\end{array}$ \\
\hline Col I & +++ & + & +++ \\
Col II & - & +++ & - \\
Col III & +++ & - & + \\
Col IV & +++ & + & ++ \\
Col V & - & + & - \\
Col VII & $?$ & $?$ & - \\
Col IX & - & ++ & - \\
\hline
\end{tabular}

on adjacent tracks of Col IV and Col VII they showed a clear preference for Col IV (Fig. 7F), confirming that Col VII was nonpermissive as a migratory substratum.

\section{Col-IV-low density heparan sulfate proteoglycan} ( $L D P G)$ complexes

In basement membranes, Col IV is thought to form a skeletal network that is interwoven with lamininnidogen-heparan sulfate proteoglycan complexes (Yurchenco et al. 1986; Yurchenco and Schittny, 1990). Intact dimers of Col IV bound to immobilized LDPG in a dose-dependent and saturable manner, by an interaction that may involve the heparan sulfate chains of the proteoglycan (Table 3 ). We tested whether binding of Col IV to LDPG affected its ability to stimulate avian neural crest cell movement and found that LDPGbound Col IV lost much of its motility-promoting activity (Table 1). It is unlikely that this loss was simply due to decreased availability of the substratum molecule since the amount of Col IV bound to LDPG was only about $25 \%$ lower than that of Col IV bound directly to plastic (not shown). Moreover, saturation of neural crest cell migration on Col IV is reached at a concentration below the maximal bound to LDPG (Perris et al. 1991b).

Effect of fibronectin, laminin-nidogen, tenascin and cartilage proteoglycan (PG-LA) on neural crest cell migration on polymerized $\mathrm{Col} I$

To examine the extent to which the interaction of neural crest cells with Col I could be modulated by other matrix constituents, we tested various types of Col I substrata in combination with motility-promoting or motility-inhibitory matrix components. Inclusion of fibronectin during polymerization of $\mathrm{Col} \mathrm{I}$ enhanced neural crest cell migration in a dose-dependent manner, with a 3 -fold increase at a concentration of $100-300 \mu \mathrm{g} \mathrm{ml}^{-1}$ (Fig. 11A). Laminin-nidogen, however, was 10- to 100 -fold less efficient and tenascin was completely ineffective in altering neural crest cell movement on polymeric Col I (Fig. 11A). Increasing concentrations of PG-LA inhibited neural crest cell movement on polymeric Col I, causing a significant inhibition at $100 \mu \mathrm{g} \mathrm{ml}^{-1}(53 \%, P<0.001)$ and almost complete blockage of cell migration at $1000 \mu \mathrm{g} \mathrm{ml}^{-1}$ ( $84 \%$, Fig. 11B). 
Table 3. Solid-phase interactions of biotinylated collagens with each other and with other matrix molecules

\begin{tabular}{|c|c|c|c|c|c|c|c|c|}
\hline \multirow{2}{*}{$\begin{array}{l}\text { Immobilized } \\
\text { molecule }\end{array}$} & \multicolumn{7}{|c|}{$\begin{array}{l}\text { Added molecule } \\
\text { Collagen type }\end{array}$} & \multirow[b]{2}{*}{ FN } \\
\hline & I & $\Pi$ & III & IV & V & VII & & \\
\hline $\begin{array}{l}\text { Col I M } \\
\text { Col. I DP }\end{array}$ & $\overline{-}$ & $\overline{\text { n.t. }}$ & $\begin{array}{l}+ \\
\text { n.t. }\end{array}$ & $\begin{array}{c}- \\
\text { n.t. }\end{array}$ & $\begin{array}{c}+ \\
\text { n.t. }\end{array}$ & $\begin{array}{c}+ \\
\text { n.t. }\end{array}$ & $\overline{\text { n.t. }}$ & $\begin{array}{l}+++ \\
+++\end{array}$ \\
\hline $\mathrm{Col} \mathrm{I}+\mathrm{CBFNf}$ & & & & & & & & + \\
\hline Col II & - & - & - & - & - & - & - & +++ \\
\hline Col III & + & - & - & - & - & - & - & ++ \\
\hline Col IV & - & - & - & $t^{*}$ & - & - & + & + \\
\hline Col V & ++ & - & - & - & - & - & - & +++ \\
\hline Col VII & - & - & - & + & - & - & - & - \\
\hline $\begin{array}{l}\text { LDPG } \\
\text { LDPG-Hep }\end{array}$ & - & - & - & $\begin{array}{c}+++ \\
+\end{array}$ & - & - & - & n.t. \\
\hline
\end{tabular}

Note: FN, fibronectin; Col I M, monomeric Col I; Col I D, dehydrated polymeric Col I; CBFNf, collagen-binding fragment of fibronectin $\left(M_{\mathrm{r}} 40000\right)$; LDPG, low-density heparan sulfate proteoglycan; LDPG-Hep, heparitinase-treated low-density heparan sulfate proteoglycan.

* Col IV self-assembles at high concentrations and subphysiological temperatures (Yurchenco et al. 1986; Yurchenco and Schittny, 1990; Perris et al. 1991b).
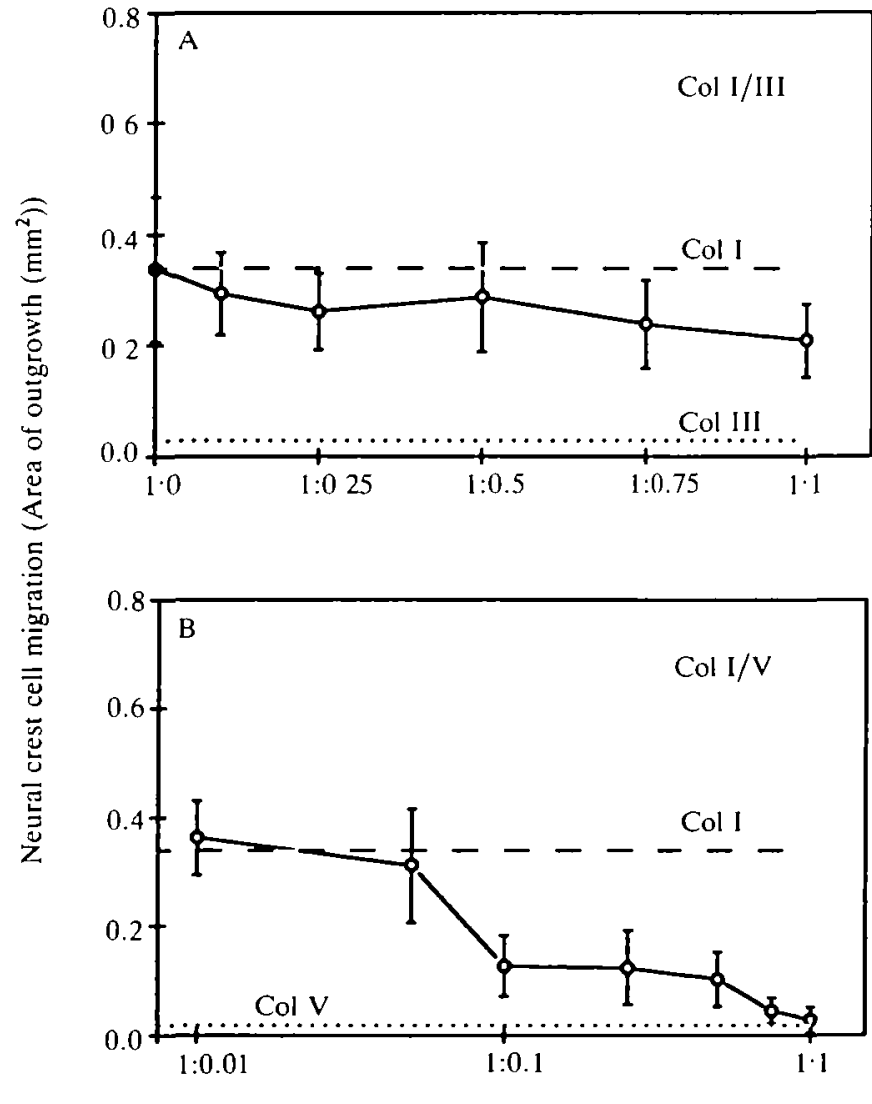

Relative mass ratio

Fig. 9. Neural crest cell migration on composite collagen substrata in which various mass ratios of Col III (A; Col I/III) or Col V (B; Col I/V) were co-polymerized with Col I (i.e. Col III and $V$ were added at the given ratios to the neutralized Col I solution prior to polymerization). The 'base-line' neural crest cell migration on hydrated polymeric Col III and Col $\mathrm{V}$ alone is indicated for comparison.
While copolymerization of fibronectin or lamininnidogen with Col I influenced neural crest cell migration, addition of soluble fibronectin or lamininnidogen to cells migrating on already polymerized $\mathrm{Col} \mathrm{I}$ substrata (2-4h after plating of the cells) did not significantly alter the extent of cell dispersion (Table 1).

\section{Neural crest cell migration on fibronectin bound to pre-immobilized collagen}

Fibronectin bound to pre-immobilized monomeric Col I, dehydrated fibrillar Col I, monomeric Col II and monomeric $\mathrm{Col} \mathrm{V}$ was significantly less efficient in supporting neural crest cell movement than fibronectin bound directly to plastic (Fig. 7E; Table 1). This effect was not due to lower amounts of fibronectin in the substratum as ascertained by solid-phase binding assays (Table 3). This suggests that association of fibronectin with interstitial collagens may cause a conformational change in the molecule that modulates its ability to support neural crest cell migration.

\section{Discussion}

In this study, we have determined the in situ distribution of Col I-V and IX during avian neural crest development and examined the ability of various purified collagens to promote neural crest cell migration in vitro, in the presence or absence of other matrix molecules. In agreement with previous studies (Newgreen and Erickson, 1986; Duband and Thiery, 1987), we observed a widespread distribution of Col I along neural crest migratory pathways at all phases of migration. Col III was consistently colocalized with Col I, supporting the notion that these two collagens constitute a mutually interactive pair of matrix molecules, possibly by being copolymerized within the same fibrils (Henkel and Glanville, 1982; Keene et al. 1987b). While Col I, III, IV and V lined the notochordal basement membrane, only Col II and Col 


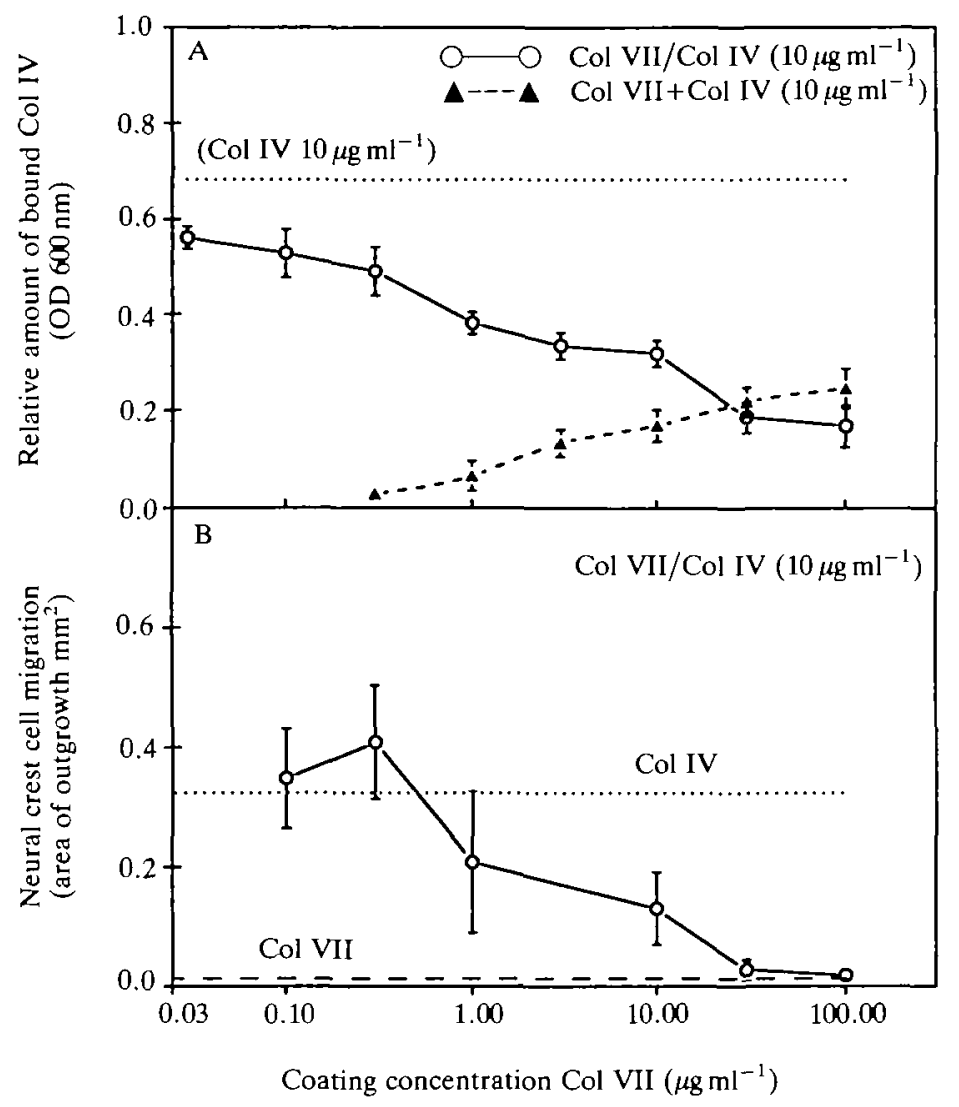

Fig. 10. Relative binding of intact Col IV dimers to a plastic surface pre-coated with increasing concentrations of the triple-helical fragment of Col VII (Col VII/Col IV; upper graph). Wells were sequentially coated with the indicated concentrations of Col VII followed by coating with $10 \mu \mathrm{g} \mathrm{ml}^{-1}$ of Col IV. A weak interaction also was detected between pre-immobilized Col VII and the intact form of Col IV (Col VII+Col IV). Data points represent averages from four tests \pm s.D. Neural crest cell migration on composite substrata with different relative proportions of Col VII and Col IV (lower graph). Cell movement on $\mathrm{Col}$ VII (at $100 \mu \mathrm{g} \mathrm{ml}^{-1}$ coating concentration) and Col IV $\left(10 \mu \mathrm{g} \mathrm{ml}^{-1}\right)$ alone is indicated for comparison.

IX were expressed in the fibrillar matrix network that extended throughout the perinotochordal space. In this region, Col II and IX occurred in a metameric pattern, appearing in regions of prospective vertebral arch formation. Thus, the metameric distribution of Col II and IX alternated with that of Col I and III, but was coincident with that of cartilage-specific proteoglycans (Perris et al. 1991a). The distribution of $\mathrm{Col} \mathrm{V}$ in embryonic basement membranes is intriguing since this collagen occurs exclusively in interstitial fibrils in adult tissues (von der Mark and Ökalan, 1982; MartinezHernandez et al. 1982; Linsenmayer et al. 1983; Modesti et al. 1984; Birk et al. 1988).

A striking reorganization of Col I and III was observed during progressive migration of neural crest cells through the rostral half of each somitic sclerotome. Fibrils of Col I and III initially were uniformly distributed throughout the sclerotome, but became gradually excluded from the rostral half with advanced neural crest cell migration and the formation of
Collagens in neural crest development

981

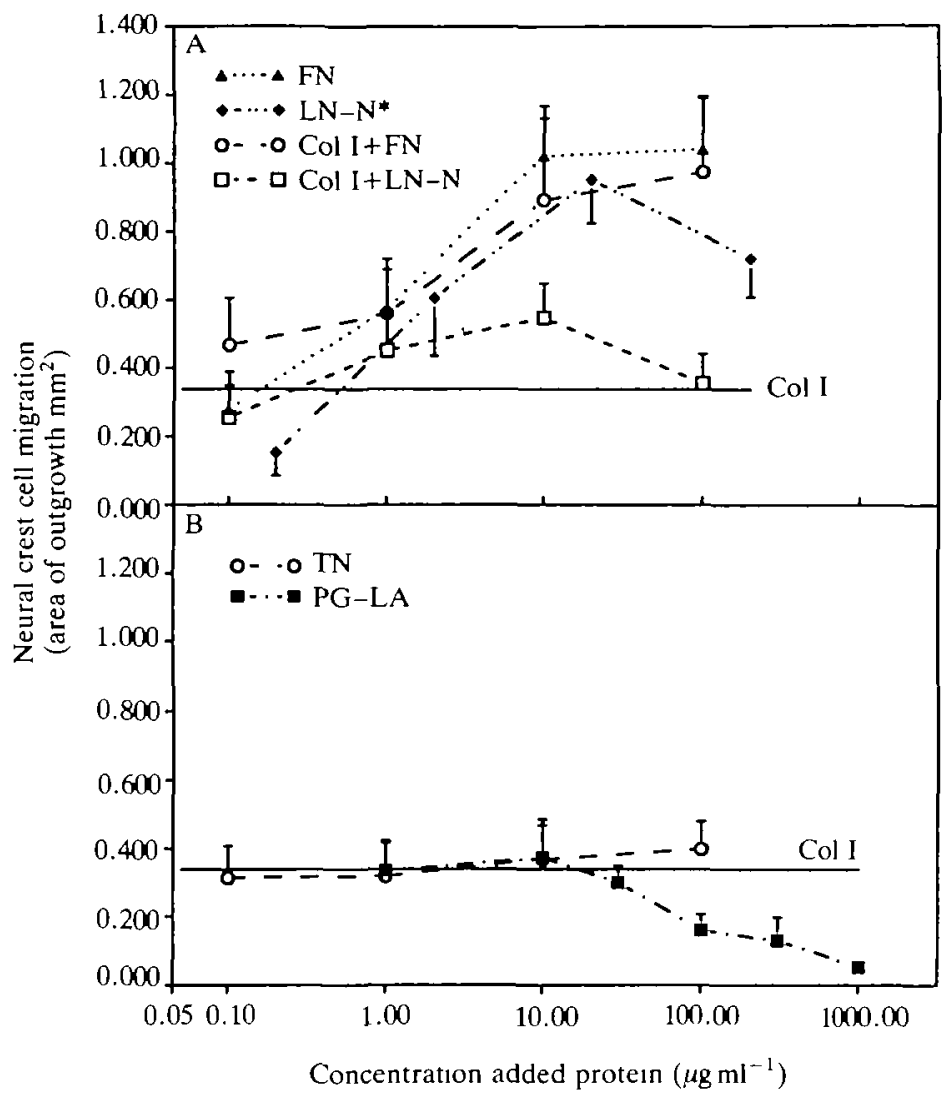

Fig. 11. (A) Neural crest cell migration on hydrated polymeric Col I substrata $\left(600 \mu \mathrm{g} \mathrm{ml}^{-1}\right)$ in which various concentrations of fibronectin (FN) or laminin-nidogen complex (LN-N) were copolymerization with Col I. Neural crest cell migration on fibronectin and laminin-nidogen bound to plastic and on polymeric $\mathrm{Col} I$ alone is indicated for comparison. * Data on neural crest cell migration on plastic-bound laminin-nidogen were derived from a previous publication (Perris et al. 1989). (B) Effect of copolymerization of $\mathrm{Col} I$ with tenascin (TN) or the bovine cartilage chondroitin sulfate proteoglycan (PG-LA) on neural crest cell migration. While tenascin did not have any significant effect on cell movement, PG-LA blocked avian neural crest cell migration in a similar fashion as reported for amphibian neural crest cells (Perris and Johansson, 1990).

peripheral ganglia. This remodelling of the interstitial collagens appears to be a direct consequence of neural crest cell migration, since Col I/III fibrils remained relatively uniform in both rostral and caudal sclerotomes of embryos in which the neural crest was ablated surgically. The mechanism responsible for the rearrangement of Col I and III fibrils within the sclerotome could be proteolytic degradation and/or mechanical displacement of the collagenous fibrils by the neural crest cells themselves or by their neighboring sclerotomal cells. Interestingly, the sclerotomal reorganization of Col 1/III fibrils is similar to that observed previously for chondroitin/keratan sulfate proteoglycans and fibronectin (Krotoski et al. 1986; Perris et al. 1991a). In contrast, Col IV, which seemed to form a fibrillar network coincident with that of Col I and III, 
laminin (Krotoski et al. 1986; Duband and Thiery, 1987) and a heparan sulfate proteoglycan (Perris et al. 1991a) remains uniformly distributed throughout the sclerotome. Tenascin, on the other hand, has been shown to become progressively rearranged to the rostral half of each sclerotome during the course of neural crest cell migration (Stern et al. 1989). Thus, it appears that the sclerotome represents an embryonic area where defined sets of interacting matrix constituents become differentially rearranged during neural crest development and morphogenesis.

Isolated Col I-VII markedly differed in their ability to support neural crest cell migration in vitro. In agreement with previous findings in amphibians (Perris and Johansson, 1990), we observed that avian neural crest cells migrated most extensively on Col I and IV and relatively poorly on other collagens. The interaction of neural crest cells with collagen did not appear to be mediated by homophilic interaction of cell surfaceassociated collagen with that in the substratum, since no collagen immunoreactivity could be detected on the surface of migrating neural crest cells in vivo and in vitro. In addition, other investigators have reported inhibitors of collagen synthesis do not significantly affect neural crest cell movement through Col I gels (Sanders et al. 1988). Attachment of fibroblastic cells to denatured collagen is potentiated by exogenous fibronectin contained in serum or secreted by the cells (Grinnell and Minter, 1978; Chiquet et al. 1979). However, neural crest cell migration on various collagens did not seem to be dependent upon cell surface-associated fibronectin. On the basis of immunofluorescence studies in vitro (Newgreen and Thiery, 1980; Bilozur and Hay, 1988; Leblanc and Perris, unpublished observations) and in vivo studies involving cDNA probes (Ffrench-Constant and Hynes, 1988), it has been established that trunk neural crest cells do not synthesize detectable amounts of fibronectin. Monomeric and dehydrated polymeric substrata of Col I bound with relatively low and equal affinity to fibronectin and yet were clearly distinguishable in their ability to promote neural crest cell movement. Neural crest cell migration on Col I substrata was unaffected by preincubation of the substratum with the collagenbinding fragment of fibronectin (which according to our binding assays strongly inhibits the collagen-fibronectin interaction), or by an antiserum to the cell-binding region of fibronectin. Furthermore, even at high concentrations, Col I-bound fibronectin was only a slightly better substratum for neural crest cell migration than the collagen alone. This observation suggests that the conformation of the fibronectin molecule, which may be altered by binding to its potential matrix ligands, determines its ability to support neural crest cell movement. Accordingly, the degree of neural crest cell migration on fibrillar fibronectin (Vuento et al. 1980 ) is significantly lower than that on unassembled fibronectin (Perris, unpublished observations). Finally, Col V bound substantial amounts of fibronectin, but lacked significant motility-promoting activity. Taken together, these results support the notion that neural crest cell migration on collagen does not require the participation of fibronectin.

The ability of polymeric Col I to support neural crest cell movement was altered by the presence of other matrix components. Although association with Col III did not significantly affect neural crest cell migration, association with $\mathrm{Col} V$ reduced cell movement. Such hybrid fibrils of Col I and Col $\mathrm{V}$ in vivo have been extensively characterized in the avian cornea (Birk et al. 1988). In the trunk region of the avian embryo, Col V was found restricted to the area around basement membranes of the notochord and ventral neural tube which are not contacted by the migrating neural crest cells. Col V has also been shown to influence the assembly of Col I in vitro (Adachi and Hayashi, 1986; Birk et al. 1988). Thus, the reduced level of neural crest cell migration on the Col I/V substratum may result from a combinatorial effect of $\mathrm{Col} V$ as a nonpermissive substratum molecule and as an inducer of alterations of the macromolecular organization of Col I.

Fibrils of Col VII are thought to anchor the interstitial matrix to basement membranes by linking $\mathrm{Col}$ I/III interstitial fibers to the Col IV-network of the membranes (Sakai et al. 1986; Keene et al. 1987a; Bächinger et al. 1990). The triple-helical fragment of Col VII did not support neural crest cell movement indicating that this collagen is not directly involved in cell-matrix interactions. Combined substrata of Col VII/Col IV supported lower levels of neural crest cell migration that Col IV alone, with the decrease in motility being directly proportional to the amount Col VII incorporated in the substratum. Thus, it seems that Col VII is an unfavorable molecule for neural crest cell motility, but cannot inhibit the motility-promoting activity of its potential matrix ligand Col IV.

It has been shown previously that exogenous fibronectin can enhance the motility of neural crest cells in Col I gels (Davis, 1980; Davis and Trinkaus, 1981; Newgreen, 1982; Newgreen et al. 1982; Turley and Erickson, 1983; Tucker and Erickson, 1984; Bilozur and Hay, 1988). Accordingly, we find that addition of fibronectin increases the extent of neural crest cell dispersion on Col I, but only when combined with the collagen during polymerization. Hence, soluble fibronectin added to already polymerized Col I did not alter neural crest cell migration. This difference may be explained by the relatively low affinity of fibronectin for native collagen (Engvall and Ruoslahti, 1977; Jilek and Hörmann, 1978; Cidadão et al. 1989). Incorporation of laminin-nidogen into polymerizing Col I substrata also altered the extent of neural crest cell migration. However, considerably higher amounts of the lamininnidogen complex were required to enhance neural crest cell motility. The observed differences been fibronectin and laminin-nidogen cannot be attributed to higher degree of dissipation of laminin-nidogen into the culture medium, since the total amount of radioactively labelled fibronectin or laminin-nidogen found in the medium after $16 \mathrm{~h}$ differs by less than $1-2 \%$ (unpublished data). The migratory response of neural crest cells to laminin-nidogen on the three-dimensional 
fibrillar substratum of Col I was similar to that of laminin-nidogen bound directly to plastic and required copolymerization with Col I.

Tenascin represents another large molecular mass glycoprotein thought to be associated with trunk neural crest cell migration (Tan et al. 1987; Mackie et al. 1988; Halfter et al. 1988; Stern et al. 1989). The presence of tenascin within Col I gels did not affect neural crest cell migration indicating that although this glycoprotein is nonpermissive as a substratum for neural crest cell migration, it does not alter the interaction of cells with collagen.

In summary, we find that Col I, III and IV are primary constituents of the extracellular matrix encountered by neural crest cells during their early migration. Col II, V and IX, on the other hand, show a restricted expression and are generally absent from the regions through which neural crest cells migrate. The differential distribution of the various collagen types, in conjunction with their differential ability to support neural crest cell migration in vitro, correlates well with a permissive function for Col I, III and IV, and a nonpermissive function for Col II, V, VII and IX. The rearrangement of $\mathrm{Col}$ I and III fibrils along neural crest migratory pathways suggests that the migrating cells may modify their collagenous matrix substratum as they move. The observation that fibronectin/collagencontaining matrices behave differently depending upon the conditions under which they are assembled suggests that proper supramolecular organization of fibronectin and/or collagen may determine the ability of these matrix molecules to support neural crest cell movement.

We are grateful to Drs Peter Bruckner, Staffan Johansson, Charles Little, Mats Paulsson, Helene Sage, and Jörgen Wieslander for providing various antibodies, purified collagens and other matrix components. Drs Robert Burgeson, Thomas Lallier and Helene Sage are thanked for their valuable suggestions and critical reading of the manuscript. Michael Artinger, Kristin Artinger, Mary Flowers and Susan Tran are acknowledged for their excellent technical assistance. The work was supported by NIH grant USPHS HD 15527 and by the Muscular Dystrophy Association.

\section{References}

ADACHI, E. AND HAYASHI, T. (1986). In vitro formation of hybrid fibrils of type $V$ collagen and type I collagen. Limited growth of type I collagen into thick fibrils by type V collagen. Conn. Tissue Res. 14, 257-266.

Bächinger, B., Morris, H. P., Lunstrum, N. P., Keene, G. P., Rosenbaum, D. R., Compton, L. M. and Burgeson, R. E. (1990). The relationship of the biophysical and biochemical characteristies of type VII collagen to the function of anchoring fibrils. J. biol. Chem. 265, 10095-10101.

Bilozur, M. E. AND HAY, E. D. (1988). Neural crest cell migration in 3D extracellular matrix utilizes laminin, fibronectin, or collagen. Devl Biol. 125, 19-33.

Birk, D. E., Fitch, J. M., Babiarz, J. P. and Linsenmayer, T. L. (1988). Collagen type I and type $V$ are present in the same fibril in the avan corneal stroma. J. Cell Biol. 106, 999-1008.

BruckNer, P., VAughan, L. AND Winterhalter, K. H. (1985). Type IX collagen from sternal cartilage of chicken embryo contains covalently bound glycosaminoglycans. Proc. nath. Acad. Sci. U.S.A. 82, 2608-2612.

Chiquet, M., Puri, E. C. and Turner, D. C. (1979). Fibronectin mediates attachment of chicken myoblasts to a gelatin-coated substratum. J. biol. Chem. 254, 5475-5482.

CIDADĀO, A. J. (1989). Interaction between fibronectin, glycosaminoglycans and native collagen fibrils: an EM study in artificial three-dimensional extracellular matrices. Eur. J. Cell Biol. 48, 303-312.

DAvis, E. M. (1980). Translocation of neural crest cells within a hydrated collagen lattice. J. Embryol. exp. Morph. 55, 17-31.

Davis, E. M. AND Trinkaus, J. P. (1981). Significance of cell-tocell contacts for the directional movement of neural crest cells within a hydrated collagen lattice. J. Embryol. exp. Morph. 63, 29-51.

Duband, J. L. and Thiery, J. P. (1987). Distribution of laminin and collagens during avian neural crest development. Development 101, 461-478.

EngVall, E. AND Ruoslaht1, E. (1977). Binding of soluble form of fibroblast surface protein, fibronectin, to collagen. Int. $J$. Cancer 20, 1-7.

Erickson, C. A. ANd Turley, E. A. (1983). Substrata formed by combinations of extracellular matrix components alter neural crest cell motility in vitro. J. Cell Sci. 61, 299-323.

FrRench-CONSTANT, C. AND HyNEs, R. O. (1988). Patterns of fibronectin gene expression and splicing during cell migration in chicken embryos. Development 104, 369-382.

Fitch, J. M., Gross, J., Mayne, R., Johnson-Wint, B. and LiNSENMAYER, T. F. (1984). Organization of collagen types I and $\mathrm{V}$ in the embryonic chicken cornea: monoclonal antibodies studies. Proc. natn. Acad. Sci. U.S.A. 81, 2791-2795.

GrinNell, F. AND MiNTER, D. (1978). Attachment and spreading of baby hamster kidney cells to collagen substrata: effects of cold-insoluble globulin. Proc natn. Acad. Sci. U.S.A. 75, 4408-4412.

Halfter, W., Chiquet-Ehrismann, R. and Tucker, R. P. (1989). The effect of tenascin and embryonic basal lamina on the behavior and morphology of neural crest cells in vitro. Devl Biol. 132, 14-25.

Henkel, W. and Glanvile, R. W. (1982). Covalent crosslinking between molecules of type I and type III collagen. The involvement of the $\mathrm{N}$-terminal nonhelical regions of the alpha 1(I) and alpha 2(II) chains in the formation of intermolecular crosslinks. Eur. J. Biochem. 122, 205-213.

JILEK, F. AND HOrmanN, H. (1978). Cold-insoluble globulin (fibronectin), $I^{[1,3]}$ affinity to soluble collagen of various types. Hoppe-Seyler's Z. Physiol. Chem. 359, 247-250.

Keene, D. R., Sakal, L. Y., Lunstrum, G. P., Morris, N. P. AND BURGESON, R. B. (1987a). type VII collagen forms an extended network of anchoring fibrils. J. Cell Biol. 104, 611-621.

Keene, D. R., Sakai, L. Y., Bachinger, H. P. and Burgeson, R. E. (1987b). Type III collagen can be present on banded collagen fibrils regardless of fibril diameter. J. Cell Biol. 105, 2392-2402.

Kosher, R. A. AND Solursh, M. (1989). Widespread distribution of type II collagen during embryonic chick development. Devl Biol. 131, 558-566.

Krotoski, D., Domingo, C. AND Bronner-Fraser, M. (1986). Distribution of a putative cell surface receptor for fibronectin and laminin in the avian embryo. J. Cell Biol. 103, 1061-1071.

Linsenmayer, T. F., Frtch, J. M., Schmid, T. M., Zak, N. B., Gibney, E., Sanderson, R. D. And Mayne, R. (1983). Monoclonal antibodies against chicken type $\mathrm{V}$ collagen: production, specificity, and use for immunocytochemical localization in embryonic comea and other organs. J. Cell Biol. 96, 124-132.

LÖberg J., Ahlfors, K. AND FälLSTROM, C. (1980). Neural crest cell migration in relation to extracellular matrix organization in the embryonic axolotl trunk. Devl Biol. 75, 148-167.

Mackie, E. J., Tucker, R. P., Halfter, W., Chiquet-Ehrismann, R. AND EPPERLEIN, H. H. (1988). The distribution of tenascin coincides with pathways of neural crest cell migration. Development 102, 237-250.

Martinez-Hernandez, A., Gay, S. and Miller, E. J. (1982). 
Ultrastructural localization of type $\mathrm{V}$ collagen in rat kidney. $J$. Cell Biol. 92, 343-349.

Martins-Green, M. and Erickson, C. A. (1987). Basal lamina is not a barrier to neural crest cell emigration: documentation by TEM and immunofluorescent and immunogold labelling. Development 101, 517-533.

Modesti, A., Kalebic, T., Scarpa, S., Togo, S., Grotendorst, G., LiotTA, L. A. AND Triche, T. J. (1984). Type V collagen in human amnion is a $12 \mathrm{~nm}$ fibrillar component of the pericellular interstitium. Eur. J. Cell Biol. 35, 246-255.

Müller-Glauser, W., Humbel, B., Glatt, M., Sträuli, F., Winterhalter, K. H. ANd Bruckner, P. (1986). On the role of type IX collagen in the extracellular matrix of cartulage: type IX collagen is localized to intersections of collagen fibrils. J. Cell Biol. 102, 1931-1939.

Newgreen, D. F. (1982). Adhesion to extracellular materials by neural crest cells at the stage of initial migration. Cell Tissue Res. 227, 297-317.

Newgreen, D. F. (1989). Physical influence on neural crest cell migration in avian embryos: Contact guidance and spatial restriction. Devl Biol. 131, 136-148.

Newgreen, D. F. And Erickson, C. A. (1986). The migration of neural crest cells. Int. Rev. Cytol. 10, 89-145.

Newgreen, D. F., Gibiins, I. L., Sauter, J., Wallenfels, B. AND WUTZ, R. (1982). Ultrastructural and tissue-culture studies on the role of fibronectin, collagen and glycosaminoglycans in the migration of neural crest cells in the fowl embryo. Cell Tissue Res. 221, 521-549.

Newgreen, D. F. AND Thiery, J.-P. (1980). Fibronectin in the early avian embryos: Synthesis and distribution along migration pathways of neural crest cells. Cell Tissue Res. 211, 269-291.

Perris, R. (1991). Role of proteoglycans in neural crest development. Trends Glycosci. Glycotechnol. 3, 166-175.

Perris, R. and Bronner-Fraser, M. (1989). Recent advances in defining the role of the extracellular matrix in neural crest development. Comm. Dev. Neurobiol. 1, 61-83.

Perris, R., Dillon, T. and Bronner-Fraser, M. (1991b).

Mechanisms of neural crest cell interaction with interstitial and basement membrane collagens. Devl Biol. Submitted.

Perris, R. and Johansson, S. (1987). Amphibian neural crest cell migration on purified extracellular matrix components. A chondroitin sulfate proteoglycan inhibits locomotion on fibronectin substrata. J. Cell Biol. 105, 2511-2521.

PERris, R. AND Johansson, S. (1990). Inhibition of neural crest cell migration by aggregating chondroitin sulfate proteoglycans is mediated by their hyaluronan-binding region. Devl Biol. 137, $1-12$.

Perris, R., Krotoski, D., Lallier, T., Domingo, C., Sorrell, J. M. ANd Bronner-Fraser, M. (1991a). Spatial and temporal distribution of proteoglycans during avian neural crest development. Development 111, 583-599.

Perris, R., LOfberg, J., Fällström, C., von Boxberg, Y.,
Olsson, L. and Newgreen, D. F. (1990). Structural and compositional divergencies in the extracellular matrix encountered by neural crest cells in the white mutant axolotl embryo. Development 109, 533-551.

Perris, R., Paulsson, M. and Bronner-Fraser, M. (1989). Molecular mechanisms of neural crest cell migration on fibronectin and laminin. Devl Biol. 136, 222-238.

Ranscht, B. AND Bronner-Fraser, M. (1990). T-cadherin expression alternates with migrating neural crest cells in the trunk of the avian embryo. Development 111, 15-22.

Rovasio, R., Delouvee, A., Yamada, K. M., Timpl, R. and ThIERY, J.-P. (1983). Neural crest cell migration: requirements of exogenous fibronectin and high cell density. J. Cell Biol. 96, $462-473$.

Sakal, L. Y., Keene, D. R., Morris, N. P. And Burgeson, R. E. (1986). Type VII collagen is a major structural component of anchoring fibrils. J. Cell Biol. 103, 1577-1586.

Sanders, E. J., Prasad, S. and Cheung, E. (1988). Extracellular matrix synthesis is required for the movement of sclerotome and neural crest cells on collagen. Differentiation 39, 34-41.

Stern, C., Norris, W. E., Bronner-Fraser, M., Carlson, G. J., Faissner, A., Keynes, R. J. AND SchachNer, M. (1989). $\mathrm{J} 1 /$ tenascin-related molecules are not responsible for the segmented pattern of neural crest cells or motor axons in the chick embryo. Development 107, 309-319.

Tan, S.-S., Crossin, K. L., Hoffman, S. and Edelman, G. M. (1987). Asymmetric expression in somites of cytotactin and its proteoglycan ligand is correlated with neural crest cell distribution. Proc. natn. Acad. Sci. U.S.A. 84, 7977-7981.

TUCKER, R. P. AND ERICKSON, C. A. (1984). Morphology and behavior of qual neural crest cells in artificial three-dimensional extracellular matrices. Devl Bool. 104, 390-405.

VON DER MARK, K. AND OKALAN, M. (1982). Immunofluorescent localization of type $\mathrm{V}$ collagen in the chick embryo with monoclonal antibodies. Collagen Rel. Res. 2, 541-555.

Vuento, M., Vartio, T., Saraste, M., von Bondsdorff, C.-H. AND VAHERI, A. (1980). Spontaneous and polyamine-induced formation of filamentous polymers from soluble fibronectin. Eur. J. Blochem. 105, 33-42.

Wieslander, J., Langeveld, J., Butkovski, R., Jodlovski, M., Noelken, M. ANd Hudson, B. G. (1985). Physical and immunochemical studies of the globular domain of type IV collagen. J. biol. Chem. 260, 8564-8570.

Yurchenco, P. D., Tsilibary, E. C., Charonis, A. S. and FURTHMAYR, H. (1986). Models for the self-assembly of basement membrane. J. Histochem. Cytochem. 34, 93-102.

Yurchenco, P. AND SChitTNy, J. (1990). Macromolecular architecture of basement membranes. FASEB J. 4, 1577-1590. 